\title{
Borna Disease Virus and Psychiatric Disorders: Can Viruses Influence Psychiatric Disorders?
}

\author{
Sylva Rackova and Lubos Janu \\ Psychiatric department, Medical Faculty of Charles University in Pilsen \\ MedAvante Inc. \\ Czech Republic
}

\section{Introduction}

\subsection{Psychiatric disorders and infectious diseases}

Psychiatric disorders are a wide group of diseases with a heterogeneous aetiology (genetic predisposition, environmental factors, exposure to stress, for example). Several infectious agents preferentially affect the central nervous system and these infections are associated with psychic and neurologic symptomatology. It has been suggested that some infectious diseases can influence the development and the course of several psychiatric disorders. Infectious agents of zoonotic diseases with the ability to cause persistent infections of the central nervous system and influence the development and functions of this system include Toxoplasma gondii, Borrelia burgdorferi and Borna disease virus (BDV). Other neurotropic viruses that affect humans and which are associated with neurologic and psychiatric symptoms include herpes viruses, HIV and rabies virus, among others. Toxoplasma gondii is associated with cognitive dysfunctions in infected subjects (human and animals). Studies have shown that there is a direct statistical link between incidences of schizophrenia and toxoplasmosis infection. Several studies reported significantly higher seropositivity of this infection in schizophenic patients (Torrey \& Yolken 2003). Lyme borreliosis is caused by the Gram-negative spirochete Borrelia burgdorferi, which has a high affinity with the central nervous system. There may be a long latent period between infection and the development of clinical neuropsychiatric symptoms. Several studies associated borreliosis with affective, anxiety (panic) and organic disorders and psychosis. A higher seropositivity was demonstrated in psychiatric patients compared to healthy individuals (Hájek et al., 2002).

\subsection{Borna disease virus characteristics and animal infection}

Borna disease virus (BDV) is an enveloped non-segmented negative-stranded RNA virus that belongs to the family Bornaviridae, order Mononegavirales. Examples of other virus families that belong to the order Mononegavirales are Filoviridae, Paramyxoviridae and Rhabdoviridae. Borna disease virus is a neurotropic virus that affects the central nervous system, especially limbic structures. Borna disease virus infects warm-blooded animals (birds and mammals, including humans). The clinical symptoms of BDV infection range from asymptomatic or a mild symptomatology to severe neurologic and behaviour disturbances and lethal non-purulent encephalitis. 
The BDV genome consists of a linear non-segmented single-stranded RNA with negative polarity. The genome is divided into three main gene blocks: the first codes for nucleoprotein $(\mathrm{N})$ and polymerase cofactors represented by p40 and p24 proteins, the second codes for matrix $(\mathrm{M})$ and virus envelope proteins, represented by p16 and p56 proteins, the third codes for the viral polymerase. The entry of BDV is via receptor-mediated endocytosis; protein p56 is sufficient for receptor recognition and virus entry (Briese et al., 1994; Cubitt et al., 1994). The BDV ribonucleic protein is transported into the cell nucleus where BDV transcription and replication occur. The replication of this virus in host cells is typical of the family Bornaviridae (de la Torre et al., 1994).

\subsection{History of BDV infection}

The first description of Borna disease infection was found in seventeenth century literature that describes this disease as affecting horses; later, behavioural changes in other farm animals were described. By the twentieth century, many cases of this infection in farm animals had been described, especially in horses and later in sheep; this disease causes a high mortality rate in infected animals. Borna disease virus owes its name to the town Borna in Saxony (Germany), where a large number of military horses died during an epidemic of this infection in 1885. It was originally thought that BDV only infected horses and sheep; BDV infection has since been described in other species across the world, including birds, cats, cattle, primates, rats, mice and others.

In the 1920s and 1930s the aetiology of Borna disease was discovered by Zwick and colleagues in Giessen (Germany). They successfully transmitted brain homogenates from naturally infected horses to experimental animals. Borna disease virus was isolated in the following years by Zwick, Siefried, Nicolau and Galoway (Durrwald \& Ludwig, 1997).

Borna disease virus antigens were isolated in the 1950s and 1960s (Durrwald \& Ludwig, 1997; Ludwid \& Bode, 2000) and in 1976 viral antibodies were detected in humans (Ludwig, unpublished data from 1985 in psychiatric patients (Rott et al., 1985). In the 1990s, the structures of BDV and viral RNA were described and isolated, BDV was integrated into the order Mononegavirales and the new family Bornaviridae (Durrwald \& Ludwig 1997, Ludwig \& Bode 2000) was created.

\subsection{The course of BDV infection in animals}

The symptomatology of BDV infection in animals ranges from asymptomatic, to a mild subclinical infection to lethal meningoencephalitis. The majority of infected individuals have subclinical, mild symptoms and BDV infected hosts are generally asymptomatic carriers. Some infected subjects develop relapsing mood disorders and behaviour disturbances (changes in appetite and sleeping, apathy or aggressive behaviour and cognitive impairments such as in memory or learning functions, for example) or neurological symptoms (movement or posture impairments, cramps and motor disturbances). A minority of infected animals have a lethal course of BDV infection and die from non-purulent meningoencephalitis. The course of BDV infection is influenced by several factors, including the age of animal at the time of infection, its immune status, genetic background and the type of animal, among others. This viral infection is associated with neurological, behavioural, mood and cognitive changes. This symptomatology leads to the possible connection with human psychiatric disorders such as affective and psychotic disorders and the possibility that BDV infection could contribute to the aetiology of several psychiatric disorders. 


\subsection{Epidemiology of Borna disease virus infection}

Borna disease virus infection was originally believed to be limited in horses and sheep in endemic areas in Central Europe, especially in Germany. But over the years, the use of new diagnostics methods discovered the presence of natural BDV infections in other regions, such as Australia, the United States of America (Kao et al., 1993; Richt et al., 2000), China (Hagiwara et al., 2001), the United Kingdom (Reeves et al., 1998), Japan (Watanabe et al., 2006), Israel (Teplitski et al., 2003), other European countries (Italy, Poland, Czech Republic, France, Switzerland) (Galabru et al., 2000; Pisoni et al., 2007) and others. Natural BDV infection was detected not only in horses and sheep but also in other animal species: cats (Berg et al., 2001; Reeves et al., 1998), dogs (Weissenbock et al., 1998), cattle (Watanabe et al., 2006), birds (Berg et al., 2001), foxes (Dauphin et al., 2001), and ostriches (Weismann et al., 1994). Borna disease virus infection differs in its course according to the species; the most serious form of Borna disease is described in horses and sheep with severe neurologic symptoms and high mortality rates, in contrast to other species (Ludwig \& Bode 2000).

\subsection{The transmission of BDV infection}

There are several supposed routes of transmission of BDV infection between humans and animals: by direct contact with infectious secretions through the nasal mucosa (Durrwald \& Ludwig 1997; Hatalski et al., 1997; Ludwig and Bode 2000; Richt et al., 1993, 2000, 2001), vertically during pregnancy (Hagiwara et al., 2000; Okamoto et al., 2003), and indirectly by infected (contaminated) food or water (Durrwald \& Ludwig 1997; Hatalski et al., 1997; Ludwig \& Bode 2000; Richt et al., 1993, 2000, 2001). Findings of BDV RNA and proteins in peripheral blood mononuclear cells indicate the possibility of hematogenous transmission (Solbrig et al., 2003; Vahlenkamp et al., 2000). Pisoni and colleagues reported the possible sexual transmission of BDV infection. They detected higher BDV seropositivity in sexually active female horses compared to lower BDV seropositivity in animals that had never had sexual contact (Pisoni et al., 2007). Human-to-human transmission of BDV infection is supported by several studies that described higher BDV positivity in mental health workers and family members who were in contact with BDV-positive psychiatric patients (Chen et al., 1999a). Some studies described higher BDV positivity in humans who were in contact with infected animals; this BDV positivity was positively correlated with the degree of contact with infected animals. These findings proved the animal-to human transmission of BDV infection, which is typical of zoonotic infections (Takahashi et al., 1997; Thomas et al., 2005; Weismann et al., 1994).

Infected rodents and wild birds are considered to be reservoirs of BDV infection (Berg et al., 2001), but pets and farm animals represent a greater risk of human BDV infection because of the closer contact with them. Experimentally infected rodents developed persistent BDV infection, which is associated with the presence of the virus in saliva, urine and faeces. Borna disease virus was also found in the excrement of migrating birds. These reports suggest that wild birds could be a reservoir because of the possibility of water or food contamination by infected secretions.

The most frequent route of BDV infection transmission is probably via contact with infected saliva or other secretions through the nasal mucosa. The olfactory route of BDV transmission is efficient; the olfactory bulbs in naturally infected horses show oedema and inflammation early in the course of infection. After infection, BDV initially replicates in the neuroreceptor cells of the olfactory epithelium; then, BDV spreads intra-axonally and transsynaptically towards olfactory structures and then preferentially to the limbic system. In the 
nuclei of infected neurons, aggregates of virus material form Joest-Degen inclusion bodies that are typical of BDV infection. The spread of this virus is not just restricted to the limbic system; during later stages of infection BDV diffuses though the central nervous system and can be detected in oligodendrocytes, astrocytes, Schwann cells and ependymal cells in the peripheral nervous system. In the late stages of BDV infection the virus spreads centrifugally and virus markers can be detected in the peripheral nerves of all tissues. The spread of BDV infection within the CNS is mediated by ribonucleoprotein particles rather than by the enveloped virus. A minimum incubation period of 3 to 4 weeks is estimated for horses and sheep with nonspecific signs such as hyperthermia, anorexia, colic and constipation in the initial phase (Carbone et al., 1987; Gonzales-Dunia et al., 1997, 2000; Gosztonyi \& Ludwig, 1984, 2001).

\subsection{Mechanism of action, persistent infection, and the course of infection}

Borna disease virus can cause persistent infection in the central nervous system. Persistent viral infection is characterized as circumstances in which the virus is not cleared but remains in the cells of infected individuals. There are three types of persistent viral infection: latent, chronic and slow infection. The latent type of persistent infection is typical of BDV. Latent infection is associated with a lack of demonstrable viral particles. The reactivation of persistent latent BDV infection can be triggered by several stimuli: super-infection by other infectious agents, trauma, stress factors, medication or other diseases that lead to changes in immune system. After reactivation, it is possible to detect viral structural proteins that interfere with neurotransmitter receptors and their functions. During infection, BDV influences the central nervous system in several ways: firstly, there is a direct influence through the binding of viral proteins with neurotransmitter receptors (monoamine, serotonin and dopamine systems), and secondly there is an indirect influence though the immune response and inflammatory reactions. Both types of mechanisms contribute to neurotransmitter changes and lead to mood, emotional or behaviour changes in infected subjects, and they may also be associated with psychiatric disorders. The severity of clinical symptoms and the course of BDV infection depend on several factors: immune status and response of the host, the age at infection, and genetic vulnerability (predisposition) to the development of psychiatric disorders, among others (Dietrich et al., 1998). The third mechanism by which BDV can possibly influence CNS functions is due to the fact that viral infections are able to influence the human genome. Some human genetic material originates from viruses and viral sequences being assimilated into the host genome. After infection, BDV sequences are integrated into the genome of brain cells. These sequences are not heritable but they can cause mutations that interfere with brain functioning and can contribute to the development of psychiatric disorders (Feschotte, 2010).

\subsubsection{Borna disease virus and its influence on the central nervous system}

Animal models have been used to study and help explain the influence of BDV infection on the central nervous system. Changes in several neurotransmitter receptors have been described. Research on adult experimental rats has shown how BDV infection causes longterm changes in cognition, emotions and behaviour. Research on neonatal animals has explained how BDV infection influences brain development with subsequent changes in behaviour and cognition. 
Changes in the dopamine system of infected adult rats were described, where disturbances were found in the levels of dopamine in the caudate-putamen (D2 receptors) and the nucleus accumbens (D2 and D3 receptors): pre- and postsynaptic sites of dopamine receptors were damaged in the striatum, dopamine reuptake sites were reduced in the caudate-putamen and nucleus accumbens, postsynaptic D2 receptors were reduced in the caudate-putamen and D2 and D3 receptor binding was decreased in the nucleus accumbens. Postsynaptic dopamine receptors (D1 and D2) remain intact in the prefrontal cortex; this imbalance leads to D1 hypersensitivity and neurobehavioural disturbances in BDV-infected animals. Partial dopamine deafferentation and compensatory hyperactivity of the remaining striatal nerve terminals in the nigrostriatal projections are associated with locomotor activity and stimulant sensitivity. Decreased numbers of dopamine D2 and D3 receptors and the remaining numbers of D1 receptors in the striatum are associated with dyskinesias and dystonia (Solbrig et al., 1994, 1996, 2000, 2010). These changes in dopamine neurotransmission support a connection between BDV and neuropsychiatric disorders such as schizophrenia and addiction and extrapyramidal disorders.

In addition to the altered dopamine system the dysfunction of serotonin and noradrenergic systems is present and is associated with other symptoms. There is evidence of a serotonin system dysfunction in the striatum and norepinephrine dysregulation in the prefrontal and anterior cingulate cortex. Changes caused by BDV infection include reduced serotonin transmission, which is associated with autistic disorders and depression.

The course of BDV infection in adult rats is more severe in comparison to infected neonate rats, which have a milder symptomatology in BDV infection. These animals developed behaviour and cognitive changes, learning difficulties, increased motor activity, abnormal anxiety responses, deficits in motor coordination and postural stability and impairments in social behaviour, and they also showed abnormally early locomotor development. They also showed altered circadian rhythms and appetite changes. Damage to or dysfunction in the CNS of these animals is associated with direct viral effects on the morphogenesis of the hippocampus and cerebellum (Dietz et al., 2004; Pletnikov et al., 2000, 2001, 2002; Solbrig et al., 2010). Borna disease virus infection impairs synaptic plasticity, which is important for learning and memory (Volmer et al., 2007).

Behaviour disturbances were reported in other experimentally infected animals: altered social and sexual behaviours such as abnormal dominance relationships and a failure to mate were described in primates (tree shrews and rhesus monkeys). Rhesus monkeys were initially hyperactive and later became apathetic (Sprankel et al., 1978; Stitz et al., 1980).

Neonatal Borna disease virus infection in rats is associated with the activation of microglia and astrocytes and the loss of neurons in the dentate gyrus in the hippocampus, cortex and cerebellum (Gonzales-Dunia et al., 2000; Pletnikov et al., 2002; de la Torre, 2002). Ovanesov and colleagues were the first to find a significant increase in microglial activation and secondary neuronal loss (Ovanesov et al., 2008). Borna disease virus infection also affects astrocytes, which play an essential role in the maintenance of homeostasis in the CNS. Borna disease virus infection is also associated with impairment in the ability of astrocytes to take up glutamate; this impairment leads to increased levels of extracellular glutamate, the activation of NMDA receptors and an increased calcium influx, and results in neurotoxicity and cell death (Billaud et al., 2000).

In the pathogenesis of Borna disease, Borna disease virus infection also plays an important role in the inflammatory reaction (the BDV-specific T-cell response and the activity of CD8+ 
T-cells cause the destruction of virus-infected neurons). The inflammatory reaction is associated with the symptomatology of infection (Stitz et al., 1995).

\subsubsection{Viro-psycho-immunological disease model and schematic (in connection with psychiatric disorders)}

The connections between viral infections, stress and immune functions are described and explained by the viro-psycho-immunological disease model. Acute or chronic stress or other factors (other infections, diseases, immunosupressive medications, for example) cause changes in immune functions. These alterations in the immune system are responsible for the reactivation of latent forms of $\mathrm{BDV}$ infection in the central nervous system. The reactivation of BDV directly influences CNS function due to the affinity of viral proteins to neurotransmitter receptors and indirectly influences it via the inflammatory reaction, which also leads to changes in neurotransmission. Individuals with a greater vulnerability (predisposition) for developing psychiatric disorders (genetic disposition) can develop psychiatric symptoms (Dietrich et al., 1998) (see Figure 1).

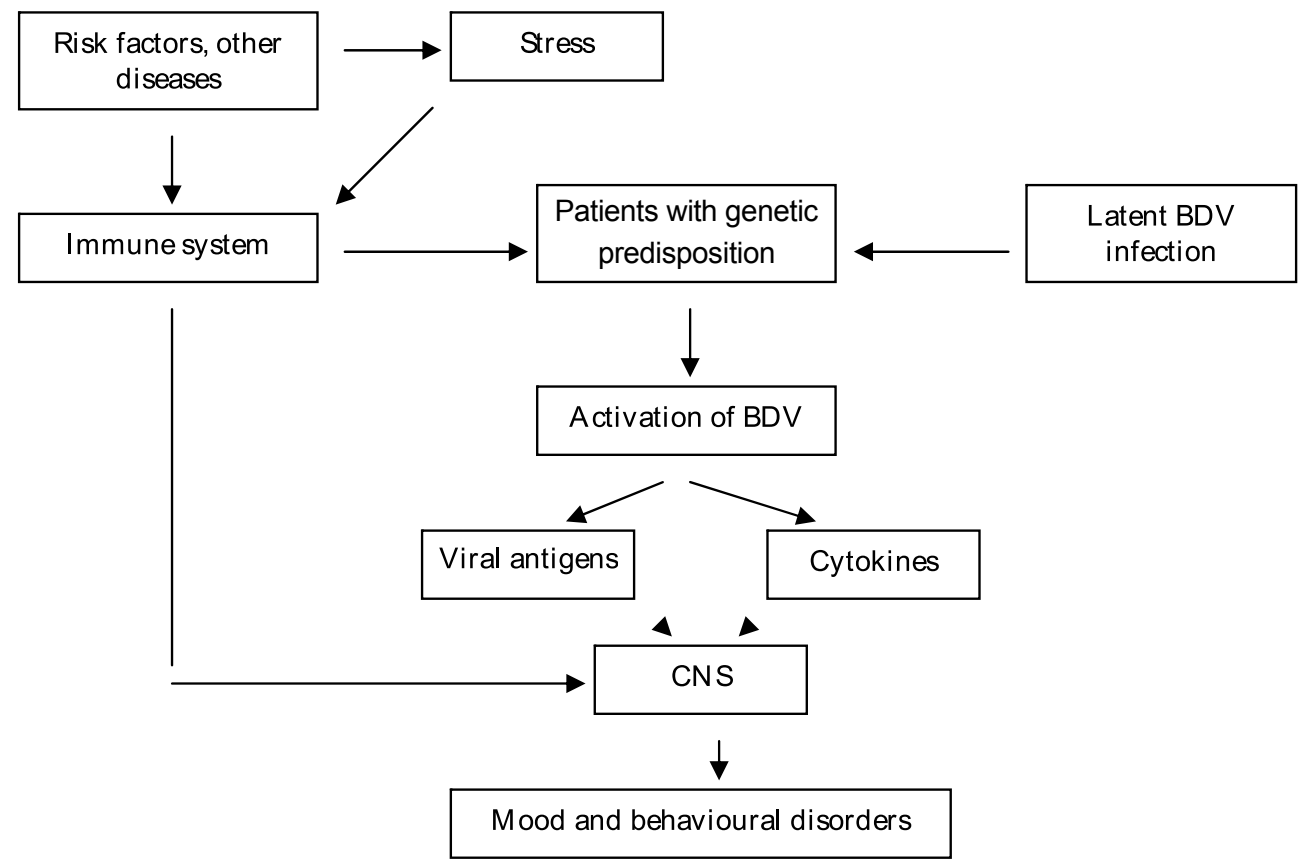

Fig. 1. Viro-psycho-immunological disease model of BDV infection and psychiatric disorders adapted from Dietrich et al., 1998

\subsection{Laboratory diagnosis of BDV infection}

The aims of laboratory diagnostics in BDV are the detection of BDV infection and the determination of infectious activity and its severity. Several questions can be asked: is the patient infected by BDV? Is this infection active? How intense or severe is this infection? Is treatment of BDV infection suitable? 
Borna disease virus antigens $(\mathrm{Ag})$, antibodies $(\mathrm{Ab})$, circulating immunocomplexes $(\mathrm{CIC})$ and viral ribonucleic acid (RNA) can be isolated and detected in brain tissue, cerebrospinal fluid (CSF), serum, plasma or in peripheral blood mononuclear cells (PBMCs).

The original diagnostics for BDV infection consisted of the detection of viral $\mathrm{Ab}$ via serological methods, especially immunofluorescence assays (IFA). These methods, which only detected BDV $\mathrm{Ab}$, were not very sensitive and were not able to detect acute phases of BDV infection. Enzyme-linked immunosorbent assays (ELISA) were based on recombinant viral proteins and were used in several studies to detect BDV Ab, but they showed a surprisingly low sensitivity, which could explain the differences found in the study results. The use of electrochemiluminescence immunoassays (ECLIA) did not show any great advantages in the diagnosis of BDV infection.

Another laboratory method that has been used for the detection of BDV Ab is Western blotting (WB), but this was found to be less sensitive than new-generation ELISAs with native viral antigens. Positivity of BDV Ab can indicate a persistent form of infection (in the absence of active BDV infection) or previous contact with this infection, but not an acute state. The absence of BDV $\mathrm{Ab}$ in the serum does not mean the BDV infection result is negative; antibodies bind antigens and form circulating immunocomplexes.

Antigenaemia indicates an acute and productive phase of infection. During this phase of BDV infection antibodies bind to the viral antigens and form CIC, which are measurable for weeks or months. The frequency and stability of BDV CIC make them easily available screening markers of BDV infection. By using the ELISA method, it is possible to detect viral Ag in plasma. The disadvantage of this method of detection is the very short period of antigenaemia in the acute phase of BDV infection and the high risk of false negative results after the formation of BDV CIC.

Bode and colleagues developed an ELISA (triple ELISA) method that mainly detects BDV CIC but also free BDV antigens and antibodies (Bode et al., 2001).

Several authors used the detection of viral RNA in PBMCs (peripheral blood mononuclear cells) in brain tissue via polymerase chain reaction (PCR) for the diagnosis of BDV infection. However, other researchers did not use this method for the diagnosis of BDV infection and do not recommend RNA detection as the best diagnostic tool. The first reason is due to the possibility of sample contamination during the laboratory procedure (although contamination should not occur when the detection of BDV RNA is performed according to international security instructions). The second reason is because the absence of BDV RNA in samples does not exclude the possibility of BDV infection, since RNA detection is less reliable than the detection of other virus particles (Ag or CIC) because of the low replication rate of this virus and the small amount of RNA in PBMCs. Also, the presence of BDV RNA in the brain does not necessarily reflect an active state of BDV infection (Bode et al., 2001, Sauder \& de la Torre, 1998; Thakur et al., 2009; Wolff et al., 2006).

Currently, the detection of BDV CIC by ELISA and viral isolation from PBMCs are recommended as the best screening methods of active BDV infection because of their relative stability and frequency. The best indicators (markers) of viral disease are antigen ELISA and CIC ELISA, which also both correlate well with the severity of the BDV infection. The ELISA method for the detection of BDV CIC was developed by Bode and Ludwig (Bode et al., 2001). Table 1 shows a summary of the diagnostic methods. 


\begin{tabular}{|c|c|c|c|c|c|c|c|}
\hline Test & Sample & $\begin{array}{l}\text { Diagnostic } \\
\text { parameter }\end{array}$ & Antigen & Sensitivity & Specificity & \begin{tabular}{|l|} 
Indicative \\
of infection
\end{tabular} & $\begin{array}{l}\text { Indicative } \\
\text { of disease }\end{array}$ \\
\hline $\begin{array}{l}\text { Complement } \\
\text { fixation }\end{array}$ & serum & $\mathrm{Ab}$ & Native & Low & Good & Low & Poor \\
\hline $\begin{array}{l}\text { Double } \\
\text { diffusion }\end{array}$ & serum & $\mathrm{Ab}$ & Native & Low & Good & Low & Poor \\
\hline \multirow[t]{2}{*}{ IFA } & serum & $\mathrm{Ab}$ & $\begin{array}{l}\text { Altered by } \\
\text { fixation }\end{array}$ & Good & Very good & Good & Poor \\
\hline & CSF & & & Poor & Very good & Very good & Poor \\
\hline Cell ELISA & serum & $\mathrm{Ab}$ & $\begin{array}{l}\text { Altered by } \\
\text { fixation }\end{array}$ & Low & Good & Low & Poor \\
\hline ECLISA & serum & $\mathrm{Ab}$ & Recombinant & Good & Very good & Good & Poor \\
\hline $\begin{array}{l}\text { Recombinant } \\
\text { ELISA }\end{array}$ & serum & $\mathrm{Ab}$ & Recombinant & Good & Good & Good & Poor \\
\hline Ab ELISA & serum & $\mathrm{Ab}$ & Native & Excellent & Excellent & Very good & Poor \\
\hline $\begin{array}{l}\text { Cell Ag } \\
\text { ELISA }\end{array}$ & PBMCs & $\mathrm{Ag}$ & Native & Low & Excellent & Good & Good \\
\hline \multirow{2}{*}{$\begin{array}{l}\text { Plasma Ag } \\
\text { ELISA }\end{array}$} & serum & $\mathrm{Ag}$ & Native & Good & Excellent & Very good & Excellent \\
\hline & CSF & $\mathrm{Ag}$ & Native & Low & Excellent & Very good & Excellent \\
\hline CIC ELISA & serum & CIC & Native & Excellent & Excellent & Excellent & Excellent \\
\hline \multirow[t]{2}{*}{ WB } & serum & $\mathrm{Ab}, \mathrm{Ag}$ & Denatured & Low & Very good & Good & Poor \\
\hline & CSF & & & Poor & Very good & Very good & Very good \\
\hline $\begin{array}{l}\text { Flow } \\
\text { cytometry }\end{array}$ & PBMCs & $\mathrm{Ag}$ & $\begin{array}{l}\text { Mild } \\
\text { fixation }\end{array}$ & Good & Very good & Good & Good \\
\hline \multirow[t]{3}{*}{ RT-PCR } & PBMCs & RNA & & Very good & Excellent & Very good & Poor \\
\hline & brain & RNA & & Good & Excellent & Very good & Poor \\
\hline & serum & RNA & & Low & Excellent & Very good & Good \\
\hline \multirow[t]{2}{*}{ Isolation } & PBMCS & virus & & Poor & Excellent & Excellent & Very good \\
\hline & brain & virus & & Poor & Excellent & Excellent & Very good \\
\hline
\end{tabular}

Table 1. Diagnostic tools for the detection of Borna disease virus infection in humans (Thakur et al., 2009), abbreviations explained in text

\subsection{Factors influencing BDV positivity}

Borna disease virus positivity in psychiatric patients ranges from negative to highly positive. These differences in positivity can be caused by several factors; features of the psychiatric population (age, diagnosis, severity of the psychopathology, immune status), geographical region, differences in specificity and sensitivity of the laboratory methods used and which diagnostic parameters (Ab, Ag, CIC or RNA) are detected and which biological material (brain tissue, cerebrospinal fluid, serum) is used. Other factors include the seasonal occurrence of BDV infection and contact with animals.

\subsubsection{BDV positivity and age}

Several studies showed a higher rate of BDV positivity in younger individuals. Patti and colleagues investigated BDV CIC positivity in children in Italy; BDV positivity was detected in $57 \%$. The prevalence of BDV infection was found to be significantly greater in children, particularly in the third year of life; then it decreased until 15 years of age, where another increase was observed (Patti et al., 2008). Another study performed by Scholbach and colleagues demonstrated higher rates of BDV Ag and CIC positivity in children. There were two age intervals of peak BDV positivity: the first was a peak at 6 months old and the 
second was a peak around 2-3 years old. These findings support the possible vertical transmission of BDV infection. Two other possible explanations for the greater prevalence of BDV infection in children than in adults are the less well-developed immune status of children and the fact that children of 2-3 years old are more likely to have greater contact with animals and their secretions, which are associated with a greater risk of BDV transmission (Scholbach et al. 2008).

\subsubsection{BDV positivity and the types of psychiatric disorder}

Borna disease virus infection was detected in psychiatric patients with various disorders; the majority of these studies detected BDV in patients with affective (bipolar and depressive) disorders and psychotic disorders (schizophrenia and schizoaffective disorders). The highest rate of BDV positivity was found in patients with bipolar and depressive disorders (Ferszt et al., 1999). Rybakowski and colleagues reported significantly higher rates of BDV $\mathrm{Ab}$ seropositivity in Polish psychiatric patients with affective-anxiety spectrum disorders and mental retardation than in healthy controls, and the rate of BDV seropositivity was significantly higher in patients with recent disease onset compared to past disease onset (10.2\% vs. 1.6\%) (Rybakowski et al., 2001).

\subsubsection{BDV positivity and psychopathology}

Several research groups reported an association between BDV positivity and the type or severity of the psychopathology. In a study performed by Iwahashi and colleagues, a significantly higher rate of BDV seropositivity was detected in schizophrenic patients with a negative symptomatology than in patients with positive symptoms (Iwahashi et al., 1998). Waltrip and colleagues detected a higher rate of BDV seropositivity in schizophrenic patients with deficit syndrome than in patients with non-deficit syndrome (Waltrip et al., 1997).

Bode and colleagues detected a higher rate of BDV seropositivity (more than 30\%) in patients with major depressive disorder and a lower rate of positivity $(8 \%)$ in patients with dysthymia (Bode et al., 1993). Ferszt and colleagues confirmed the higher rate of BDV antigenaemia in patients with affective disorders. The number of previous depressive episodes with symptoms including fatigue and concentration difficulties was positively related to BDV Ag positivity (Ferszt et al., 1999). Bode and colleagues found significantly higher rates of BDV Ag and CIC positivity (including higher values) in severely depressed patients during an acute crisis and lower rates of BDV Ag and CIC positivity (lower rates and lower amounts of $\mathrm{Ag}$ and $\mathrm{CIC}$ ) in patients with moderate depression. The severity of depressive symptoms correlated with the concentration and duration of antigenaemia (Bode et al., 2001). In study reported by Rackova and colleagues, a significantly higher rate of BDV CIC positivity was found in psychiatric patients with a more severe psychopathology than in patients with a milder symptomatology, as measured by psychiatric scales (Rackova et al., 2009).

\subsubsection{Regional occurrence of BDV infection}

Naturally occuring Borna disease virus infection is still confined to several areas of Central Europe, these regions are endemic for this infection. The presence of BDV infection in animals and humans has been detected not only in European areas but across the world (China, Japan, Israel and several other countries) (Durrwald \& Ludwig 1997, Ludwig \& Bode 2000). 


\subsubsection{BDV positivity and laboratory methods used}

The high variability found for BDV positivity in humans can be influenced by the laboratory method used since they differ in terms of sensitivity and specificity. Another factor that can influence the detection of BDV infection is the infectious marker used: antibody, antigen, circulating immunocomplex or RNA.

The detection of BDV CIC by ELISA has shown a 10-fold higher incidence of BDV infection than was estimated for BDV Ab positivity by the immunofluorescence method in psychiatric patients with affective disorders. The rates of positivity of BDV Ab by IFA were $11 \%$ and $20 \%$ in patients with depression and $2 \%$ in blood donors vs. CIC positivity of $62 \%, 52 \%$ and $24 \%$ in the same groups (Bode et al., 2001). Similar results were reported by Bode and colleagues in 1994, where BDV Ab positivity was detected in $20 \%$ of psychiatric patients compared to the higher positivity of BDV Ag in $40-50 \%$ of the same psychiatric patients (Bode et al., 1994). Wolff and colleagues did not confirm these results. They analysed plasma samples with a high reactivity in the ELISA assay (high positivity of BDV antigens) by immunoaffinity purification and highly sensitive real-time RT-PCR (polymerase chain reaction): neither method provided any evidence for the presence of viral proteins or nucleic acids (Wolff et al., 2006).

\subsubsection{Seasonal occurrence of BDV infection}

Borna disease virus infection shows a seasonal prevalence, being more frequent in spring and early summer. Significantly higher numbers of seropositive animals (especially sheep and horses) have been detected during these periods and a higher occurrence of clinical cases was also observed (Durrwald \& Ludwig 1997; Ludwig \& Bode 2000; Staeheli et al., 2000; Vahlenkamp et al., 2002). The number of animals that become infected and succumb to the disease differs each year, but no correlation has been described between the seasonal occurrence of BDV in animals and humans.

\subsubsection{Contact with animals}

Several studies have described an association between the prevalence of BDV infection in humans and contact with animals, which are potential reservoirs of BDV infection. Weismann and colleagues reported a significantly higher rate of BDV antibody positivity $(46 \%)$ in workers exposed to infected ostriches compared to controls $(10 \%)$. There was a strong positive correlation between the intensity of exposure and the rate of seropositivity (Weismann et al., 1994). Takahashi and colleagues found a significantly higher rate of BDV seropositivity (from $2.6 \%$ to $14.8 \%$ ) in blood donors from regions containing concentrations of horse farms compared to the BDV seropositivity of $1 \%$ in blood donors from other regions (Takahashi et al., 1997). These findings support the possible animal-to-human transmission of BDV infection. In contrast, another study from Bangladesh did not confirm this hypothesis. The authors surveyed horses and their caretakers for BDV antibody positivity and found a BDV positivity of between $25-30 \%$ in the horses but none of caretakers were positive for BDV (Khan et al., 2000). Thomas and colleagues measured BDV seroprevalence in agricultural workers in the United Kingdom. The seroprevalence was $2.3 \%$ in 1994, 3.1\% in 1996 and 2.6\% in 1999. People living or working on livestock farms had a higher rate of seroprevalence $(2.6 \%)$ than those on mixed $(2.3 \%)$ or arable $(1.6 \%)$ farms, but this was not statistically significant. Exposure to horses, sheep and cats did not increase the risk of seropositivity. Furthermore, the seropositive people were not more likely to report symptoms of psychiatric morbidity (Thomas et al., 2005). 


\subsubsection{Other factors and BDV positivity}

The activation of persistent BDV infection can be triggered by several stimuli (superinfection by other infectious agents and immunosuppressive medication, among others) that affect the immune system. This hypothesis (claim) is supported by studies reporting a higher rate of BDV positivity in HIV patients (Auwanit et al., 1996; Bode et al., 1992; Cotto et al., 2003). A lower rate of BDV seropositivity (4-8\%) was detected in the early stages of HIV infection, which then increased (13.9\%) during later stages of this disease (Bode et al., 1992).

\subsection{BDV and psychiatric disorders}

Borna disease virus infection in animals is characterized by various behavioural changes, such as changes in social behaviour, apathy, aggressive behaviour, changes in appetite and weight, and cognitive impairment, amongst others. Because these behavioural disturbances of naturally and experimentally BDV-infected animals resemble psychiatric symptoms and disorders in humans, especially affective disorders, early studies investigated a possible link between patients with these diagnoses and BDV infection. The possible connection between $\mathrm{BDV}$ infection and psychiatric disorders is explained in the viro-psycho-immunological model, shown in Figure 1 (Dietrich et al., 1998).

The earliest work that suggested a link between BDV infection and human psychiatric disorders was in 1985. Rott and colleagues examined serum samples from 979 psychiatric patients and 200 healthy volunteers for the presence of BDV Ab by indirect immunofluorescence. Borna disease virus antibodies were found in 16 of the psychiatric patients but none of the healthy volunteers. The patients who had positive serum samples also had a history of affective disorders (Rott et al., 1985).

Since 1985, several studies have demonstrated significantly higher rates of BDV infection positivity in psychiatric patients compared to healthy individuals, but several studies did not confirm these results. The rate of BVD positivity in psychiatric patients ranged from negative to highly positive (almost 100\% in patients with affective disorders).

Several researchers found a significant association between BDV positivity (levels of BDV $\mathrm{Ag}$ and CIC) and severity of the psychopathology (Bode et al., 2001; Ferszt et al., 1999; Rackova et al., 2009) and between BDV seropositivity and negative symptoms in schizophrenia (Iwahashi et al., 1998; Waltrip et al., 1997). Borna disease infection is associated with a chronic course of the disease without full remission and with recurring psychiatric disorders. The reactivation of persistent BDV infection is caused by immune changes and influences neurotransmitter systems and, in vulnerable individuals, it can contribute to the onset of a new phase of a psychiatric disorder and influence its course.

\subsection{Therapy of BDV infection}

Non-pharmacological procedures that could lead to the elimination of BDV infection were used in the past. The separation of infected animals and improvements in hygiene were recommended, but these procedures only decreased the risk of BDV infection spreading but did not eliminate the infection. Vaccination with killed vaccines and then live vaccines became available in the twentieth century, but both types of vaccine were shown to be ineffective against the Borna disease virus. Vaccination against persistent viral infection in the central nervous system cannot be recommended (Ludwig \& Bode, 2000).

Antiviral medications were also tested for the treatment of BDV infection. Hexamethylenetetramine was used for the treatment of horses, and then later hexamine 
(Ludwig \& Bode, 2000), ribavirine (Jordan et al., 1999), interferon alpha or beta (Hallensleben et al., 1999; Staeheli et al., 2001) and cyclosporine A (Stitz et al., 1989), but no effect was found on BDV infection. Some of these preparations showed a decrease in BDV replication in vitro, but they did not show efficacy in vivo.

Bechter and colleagues described several cases where an improvement in the psychic status of psychiatric patients with schizophrenia and depression was shown after cerebrospinal fluid filtration (Bechter et al., 2000).

Currently, amantadine is used for the treatment of BDV infection. Amantadine is a noncompetitive N-methyl D-aspartate-type glutamate receptor antagonist that also binds to nicotinic acetylcholine receptors. Amantadine inhibits BDV replication. Initially, amantadine-sulphate was used in the prophylaxis of influenza A (Kandel et al., 2001), in the treatment of Parkinson's disease (Brenner et al., 1989), hepatitis C (Adinolfi et al., 2003) and cocaine dependence (Kampman et al., 2000). A mild antidepressant effect of amantadine was found in a double-blind study when compared to amitriptyline and a placebo in patients with depression without BDV infection (Vale et al., 1971). Amantadine is a virostatic agent effective in the treatment of BDV infection, since it influences BDV replication in vivo.

The use of amantadine was first described in two case reports in 1991 and 1997 in the treatment of two psychiatric patients with bipolar affective disorder, where improvements in the psychiatric status of both patients were associated with the decrease and elimination of BDV positivity (Bode et al., 1997). Later, several open trials were performed to test the efficacy of this drug in psychiatric patients and amantadine-sulphate was proven to be effective in the treatment of depression in BDV positive patients (Dietrich et al., 2000; Ferszt et al., 1999); the improvement in the depressive symptomatology was correlated with a decrease in BDV infection positivity. The patients were treated with $200 \mathrm{mg}$ of amantadine per day for 12 weeks, and the majority showed significant improvements (clinical response) within the first three weeks (Dietrich et al., 2000). Ohlmeier and colleagues published the results of a double-blind trial that evaluated the effect of amantadine in the treatment of patients with the manic phase of bipolar disorder and amantadine reduced manic symptoms in BDV-infected bipolar patients (Ohlmeier et al., 2008).

\section{Aims and methods}

\subsection{Aims}

Because of the marked differences in BDV positivity in patients with different psychiatric disorders, we decided to review available studies on the detection of BDV infection in psychiatric disorders and attempt to explain these differences.

\subsection{Method}

We undertook a systematic review to determine the rate of positivity of Borna disease virus infection in psychiatric patients.

\subsection{Data sources}

PubMed, Medline, Journals@Ovid Full Text, Evidence-Based Medicine and the Cochrane database (1985-2011) were searched using the keywords 'Borna disease virus', 'psychiatric disorders' and 'prevalence' in conjunction with each of the following organic disorders, 
addictions, psychotic disorders, affective disorders and anxiety disorders. Due to variations in the laboratory methods, materials and study groups used, a meta-analysis was not possible.

\subsection{Study selection}

The inclusion criteria were studies published from 1985 to January 2011, the study participants: psychiatric patients, investigation: antibody, antigen, circulating immunocomplexes or viral RNA, material: serum, peripheral blood cells, cerebrospinal fluid, brain tissue, and outcomes: prevalence data.

\section{Results}

We identified 53 studies published from 1985 to July 2011 describing Borna disease virus positivity in psychiatric patients (psychiatric disorders, affective and psychotic disorders, addictions, neurotic disorders), 29 studies investigated viral antibodies in the serum, 23 BDV RNA in peripheral blood cells, 4 detected circulating immunocomplexes, viral antigens and antibodies in serum, 2 detected BDV RNA in cerebrospinal fluid (CFS), 5 detected BDV RNA in brain tissue and 8 studies detected BDV RNA and Ab. The prevalence of BDV infection in these studies ranged from 0 to $100 \%$ for patients with bipolar affective disorder. Between 1985 and 1993 the presence of BDV infection in groups of patients with various neuropsychiatric disorders was detected using IFA for BDV Ab. The majority of the studies identified found BDV in patients with schizophrenia and affective disorders.

\subsection{Borna disease virus infection and organic disorders}

Borna disease virus infection causes cognitive impairment (memory and learning impairment) in infected experimental animals. This impairment is linked to cholinergic loss in the forebrain and is associated with the pathology of Alzheimer's disease (Solbrig et al., 2010). Only a few studies reported BDV positivity in organic disorders, especially dementia. We identified five studies that detected the presence of BDV infection in patients with vascular and Alzheimer's dementia; the rate of BDV positivity ranged from $0 \%$ to $1 \%$ (see Table2).

\begin{tabular}{|l|l|l|l|l|l|l|}
\hline Authors & Country & Method/marker & Sample & Diagnosis & Total no. & $\begin{array}{l}\text { No. and \% of } \\
\text { positives }\end{array}$ \\
\hline $\begin{array}{l}\text { De la Torre } \\
\text { et al., 1996 }\end{array}$ & USA & PCR/Ag, RNA & Brain & Alzheimer's disease & 7 & $0 / 0 \%$ \\
\hline $\begin{array}{l}\text { Sauder } \\
\text { et al., 1996 }\end{array}$ & Germany & WB/Ab & Serum & $\begin{array}{l}\text { Alzheimer's, } \\
\text { vascular and other } \\
\text { organic disorders } \\
\text { Control }\end{array}$ & 34 & $7 / 20.5 \%$ \\
\hline $\begin{array}{l}\text { Igata et al., } \\
\text { 1998 }\end{array}$ & Japan & IFA/Ab & Serum & $\begin{array}{l}\text { Vascular dementia } \\
\text { Control }\end{array}$ & $\begin{array}{l}10 \\
36\end{array}$ & $\begin{array}{l}3 / 1.4 \% \\
0 / 11 \%\end{array}$ \\
\hline $\begin{array}{l}\text { Yamaguchi } \\
\text { et al., 1999 }\end{array}$ & Japan & ECLIA/Ab & Serum & $\begin{array}{l}\text { Alzheimer's disease } \\
\text { Vascular dementia } \\
\text { Control }\end{array}$ & $\begin{array}{l}46 \\
89 \\
917\end{array}$ & $\begin{array}{l}0 / 0 \% \\
1 / 1.12 \% \\
10 / 1.09 \%\end{array}$ \\
\hline $\begin{array}{l}\text { Czygan } \\
\text { et al., 1999 }\end{array}$ & Germany & RT-PCR/RNA & Brain & $\begin{array}{l}\text { Alzheimer's disease } \\
\text { Control }\end{array}$ & $\begin{array}{l}14 \\
52\end{array}$ & $\begin{array}{l}0 / 0 \% \\
0 / 0 \%\end{array}$ \\
\hline
\end{tabular}

Table 2. Studies that detected BDV infection in patients with organic disorders 


\subsection{Borna disease virus infection and addiction}

Borna disease virus influences dopaminergic neurotransmission, including the reward system, which plays a crucial role in the pathology of addictive disorders. We found four studies that detected BDV infection in addicted patients. Only one study detected BDV positivity in addicted patients at the start of detoxification and at the end of treatment. Rackova and colleagues demonstrated BDV CIC positivity in $36.6 \%$ and $42.9 \%$ of patients with alcohol and drug abuse; the positivity of BDV infection was not significantly higher than in healthy individuals (Rackova et al., 2010). The rate of BDV positivity ranged from negative results to positivity in $42.9 \%$ (see Table 3 ).

\begin{tabular}{|l|l|l|l|l|l|l|}
\hline Authors & Country & Method/marker & Sample & Diagnosis & $\begin{array}{l}\text { Total } \\
\text { no. }\end{array}$ & $\begin{array}{l}\text { No. and \% of } \\
\text { positives }\end{array}$ \\
\hline $\begin{array}{l}\text { Sauder } \\
\text { et al., 1996 }\end{array}$ & Germany & WB/Ab & Serum & $\begin{array}{l}\text { Alcohol and drug } \\
\text { addictions } \\
\text { Control }\end{array}$ & 22 & $1 / 4.5 \%$ \\
\hline $\begin{array}{l}\text { Yamaguchi } \\
\text { et al., 1999 }\end{array}$ & Japan & ECLIA/Ab & Serum & $\begin{array}{l}\text { Alcohol } \\
\text { addictions } \\
\text { Control }\end{array}$ & $\begin{array}{l}42 \\
917\end{array}$ & $\begin{array}{l}3 / 1.4 \% \\
10 / 1.09 \%\end{array}$ \\
\hline $\begin{array}{l}\text { Czygan } \\
\text { et al., 1999 }\end{array}$ & Germany & RT-PCR/RNA & Brain tissue & $\begin{array}{l}\text { Addictions } \\
\text { Control }\end{array}$ & $\begin{array}{l}27 \\
52\end{array}$ & $\begin{array}{l}0 / 0 \% \\
0 / 0 \%\end{array}$ \\
\hline $\begin{array}{l}\text { Rackova } \\
\text { et al., 2010 }\end{array}$ & $\begin{array}{l}\text { Czech } \\
\text { Republic }\end{array}$ & ELISA/CIC & Plasma & $\begin{array}{l}\text { Alcohol and drug } \\
\text { addictions } \\
\text { Control }\end{array}$ & $\begin{array}{l}41 \\
28 \\
127\end{array}$ & $\begin{array}{l}12 / 36.6 \% \\
12 / 42.9 \% \\
47 / 37.3 \%\end{array}$ \\
\hline
\end{tabular}

Table 3. Studies that detected BDV infection in patients with alcohol and drug addictions

\subsection{Borna disease virus infection and psychotic disorders (schizophrenia, schizoaffective disorders)}

Borna disease virus infection causes changes in dopaminergic neurotransmission in adult experimental animals and influences brain development in infected neonatal animals; these changes are important in the aetiology of psychotic disorders in humans. We identified 29 studies that detected BDV infection in patients with schizophrenia or schizoaffective disorders, 13 studies that detected BDV RNA, 9 that detected BDV Ab and 7 that detected both infectious markers: $\mathrm{Ab}$ and RNA. The rate of BDV infection positivity ranged from $0 \%$ to $63.6 \%$ in schizophrenic patients and from $0 \%$ to $13.86 \%$ in control groups of healthy individuals (see Table 4 and 5).

\subsection{Borna disease virus infection and affective disorders (depressive disorder, bipolar affective disorders)}

The first studies to detect BDV positivity in psychiatric patients reported higher rates of BDV positivity in patients with recurring affective disorders. We found 19 studies that described BDV positivity in patients with affective disorders (depressive and bipolar disorders, dysthymia), 8 studies that examined BDV RNA, 7 studies that detected BDV Ab, 2 studies that detected BDV RNA and Ag and 1 study that detected BDV CIC, Ag and Ab. The rate of BDV infection positivity ranged between $0 \%$ and $90 \%$ in patients with affective disorders. The highest positivity rate was reported in patients with bipolar depression and severe psychopathology. The rate of BDV infection was from $0 \%$ to $32 \%$ in the control group of healthy individuals (see Table 6). 


\begin{tabular}{|c|c|c|c|c|c|c|}
\hline Authors & Country & Method/marker & Sample & Diagnosis & Total no. & $\begin{array}{l}\text { No. and } \% \text { of } \\
\text { positives }\end{array}$ \\
\hline $\begin{array}{l}\text { Waltrip } \\
\text { et al., } 1995\end{array}$ & USA & $\mathrm{WB} / \mathrm{Ab}$ & Serum & $\begin{array}{l}\text { Schizophrenia } \\
\text { Control }\end{array}$ & $\begin{array}{l}90 \\
20\end{array}$ & $\begin{array}{l}13 / 14.4 \% \\
0 / 0 \%\end{array}$ \\
\hline $\begin{array}{l}\text { Sauder } \\
\text { et al., } 1996\end{array}$ & Germany & $\mathrm{WB} / \mathrm{Ab}$ & Serum & $\begin{array}{l}\text { Schizophrenia } \\
\text { Control }\end{array}$ & $\begin{array}{l}114 \\
203\end{array}$ & $\begin{array}{l}16 / 11.42 \% \\
3 / 1.4 \%\end{array}$ \\
\hline $\begin{array}{l}\text { Kubo } \\
\text { et al., } 1997\end{array}$ & Japan & $\begin{array}{l}\text { IFA/Ab } \\
\mathrm{WB} / \mathrm{Ab}\end{array}$ & Plasma & $\begin{array}{l}\text { Schizophrenia } \\
\text { Control }\end{array}$ & $\begin{array}{l}179 \\
70\end{array}$ & $\begin{array}{l}2 / 1.1 \% \\
0 / 0 \%\end{array}$ \\
\hline $\begin{array}{l}\text { Waltrip } \\
\text { et al., } 1997\end{array}$ & USA & $\mathrm{WB} / \mathrm{Ab}$ & Serum & $\begin{array}{l}\text { Negative } \\
\text { schizophrenia } \\
\text { Positive } \\
\text { schizophrenia }\end{array}$ & $\begin{array}{l}15 \\
49\end{array}$ & $\begin{array}{l}5 / 33.3 \% \\
4 / 8.2 \%\end{array}$ \\
\hline $\begin{array}{l}\text { Deuschle } \\
\text { et al., } 1998\end{array}$ & Germany & $\mathrm{EIA} / \mathrm{Ag}, \mathrm{Ab}$ & CSF & Schizophrenia & $?$ & $0 / 0 \%$ \\
\hline $\begin{array}{l}\text { Iwahashi } \\
\text { et al., } 1998\end{array}$ & Japan & $\mathrm{WB} / \mathrm{Ab}$ & Serum & $\begin{array}{l}\text { Schizophrenia } \\
\text { Control }\end{array}$ & $\begin{array}{l}67 \\
31\end{array}$ & $\begin{array}{l}30 / 44.8 \% \\
0 / 0 \%\end{array}$ \\
\hline $\begin{array}{l}\text { Chen } \\
\text { et al., 1999a }\end{array}$ & Taiwan & $\mathrm{WB} / \mathrm{Ab}$ & Plasma & $\begin{array}{l}\text { Schizophrenia } \\
\text { Family members } \\
\text { Mental health } \\
\text { workers } \\
\text { Control }\end{array}$ & $\begin{array}{l}314 \\
132 \\
82 \\
274\end{array}$ & $\begin{array}{l}38 / 12.1 \% \\
16 / 12.1 \% \\
8 / 9.8 \% \\
8 / 2.9 \%\end{array}$ \\
\hline $\begin{array}{l}\text { Yamaguchi } \\
\text { et al., } 1999\end{array}$ & Japan & ECLIA/Ab & Serum & $\begin{array}{l}\text { Schizophrenia } \\
\text { Control }\end{array}$ & $\begin{array}{l}845 \\
917\end{array}$ & $\begin{array}{l}26 / 3.08 \% \\
10 / 1.09 \%\end{array}$ \\
\hline $\begin{array}{l}\text { Tsuji } \\
\text { et al. } 2000\end{array}$ & Japan & $\mathrm{WB} / \mathrm{Ab}$ & Plasma & $\begin{array}{l}\text { Schizophrenia } \\
\text { Control }\end{array}$ & $\begin{array}{l}229 \\
229\end{array}$ & $\begin{array}{l}0 / 0 \% \\
0 / 0 \%\end{array}$ \\
\hline $\begin{array}{l}\text { Selten } \\
\text { et al., } 2000\end{array}$ & $\begin{array}{l}\text { Netherland } \\
\mathrm{s}\end{array}$ & IFA/ Ab & Serum & $\begin{array}{l}\text { Schizophrenia } \\
\text { Control }\end{array}$ & 26 & $\begin{array}{l}3 / 11 \% \\
6 / 21 \%\end{array}$ \\
\hline $\begin{array}{l}\text { Fukuda } \\
\text { et al., } 2001\end{array}$ & Japan & $\mathrm{WB} / \mathrm{Ab}$ & Plasma & $\begin{array}{l}\text { Schizophrenia } \\
\text { Control }\end{array}$ & $\begin{array}{l}45 \\
45\end{array}$ & $\begin{array}{l}2 / 4 \% \\
1 / 2 \%\end{array}$ \\
\hline $\begin{array}{l}\text { Yang } \\
\text { et al., } 2003\end{array}$ & China & $\mathrm{WB} / \mathrm{Ab}$ & Serum & $\begin{array}{l}\text { Schizophrenia } \\
\text { Control }\end{array}$ & $\begin{array}{l}116 \\
?\end{array}$ & $\begin{array}{l}10 / 8.6 \% \\
0 / 0 \%\end{array}$ \\
\hline $\begin{array}{l}\text { Terayama } \\
\text { et al., } 2003\end{array}$ & Japan & $\mathrm{WB} / \mathrm{Ab}$ & Serum & $\begin{array}{l}\text { Schizophrenia } \\
\text { Control }\end{array}$ & $\begin{array}{l}32 \\
25\end{array}$ & $\begin{array}{l}7 / 21.9 \% \\
1 / 4 \%\end{array}$ \\
\hline $\begin{array}{l}\text { Matsunaga } \\
\text { et al., } 2005\end{array}$ & Japan & $\begin{array}{l}\text { RIA/Ab } \\
\mathrm{WB} / \mathrm{Ab}\end{array}$ & Serum & $\begin{array}{l}\text { Schizophrenia } \\
\text { Control }\end{array}$ & $\begin{array}{l}57 \\
41\end{array}$ & $\begin{array}{l}8 / 14 \% \\
2 / 1 \%\end{array}$ \\
\hline $\begin{array}{l}\mathrm{Na} \\
\text { et al., } 2009\end{array}$ & Korea & IFA/Ab & Serum & $\begin{array}{l}\text { Schizophrenia } \\
\text { Control }\end{array}$ & $\begin{array}{l}60 \\
60\end{array}$ & $\begin{array}{l}0 / 0 \% \\
0 / 0 \%\end{array}$ \\
\hline $\begin{array}{l}\text { Karakose } \\
\text { et al., } 2011\end{array}$ & Turkey & ELISA/Ab & Serum & $\begin{array}{l}\text { Schizophrenia } \\
\text { Control }\end{array}$ & $\begin{array}{l}207 \\
137\end{array}$ & $\begin{array}{l}66 / 31.88 \% \\
19 / 13.86 \%\end{array}$ \\
\hline
\end{tabular}

Table 4. Studies that detected BDV Ab in patients with schizophrenic disorders 


\begin{tabular}{|c|c|c|c|c|c|}
\hline Authors & Country & Sample & Diagnosis & Total no. & $\begin{array}{l}\text { No. and } \% \text { of } \\
\text { positives }\end{array}$ \\
\hline $\begin{array}{l}\text { Sierra-Honigmann } \\
\text { et al., } 1995\end{array}$ & USA & CSF & Schizophrenia & 48 & $0 / 0 \%$ \\
\hline $\begin{array}{l}\text { Igata-yi } \\
\text { et al., } 1996\end{array}$ & Japan & $\begin{array}{l}\text { Plasma } \\
\text { PBMCs }\end{array}$ & $\begin{array}{l}\text { Schizophrenia } \\
\text { Control }\end{array}$ & $\begin{array}{l}49 \\
36\end{array}$ & $\begin{array}{l}5 / 10.2 \% \\
0 / 0 \%\end{array}$ \\
\hline $\begin{array}{l}\text { Sauder } \\
\text { et al., } 1996 \\
\end{array}$ & Germany & $\begin{array}{l}\text { Plasma } \\
\text { PBMCs }\end{array}$ & $\begin{array}{l}\text { Schizophrenia } \\
\text { Control }\end{array}$ & $\begin{array}{l}11 \\
23\end{array}$ & $\begin{array}{l}7 / 63.6 \% \\
0 / 0 \%\end{array}$ \\
\hline $\begin{array}{l}\text { Kubo } \\
\text { et al., } 1997 \\
\end{array}$ & Japan & $\begin{array}{l}\text { Plasma } \\
\text { PBMCs }\end{array}$ & $\begin{array}{l}\text { Schizophrenia } \\
\text { Control }\end{array}$ & $\begin{array}{l}? \\
12 \\
\end{array}$ & $\begin{array}{l}0 / 0 \% \\
0 / 0 \% \\
\end{array}$ \\
\hline $\begin{array}{l}\text { Lieb } \\
\text { et al., } 1997\end{array}$ & Germany & $\begin{array}{l}\text { Plasma } \\
\text { PBMCs }\end{array}$ & $\begin{array}{l}\text { Schizophrenia } \\
\text { Schizoaffective disorders }\end{array}$ & $\begin{array}{l}59 \\
10\end{array}$ & $\begin{array}{l}0 / 0 \% \\
0 / 0 \%\end{array}$ \\
\hline $\begin{array}{l}\text { Richt } \\
\text { et al., } 1997 \\
\end{array}$ & Germany & $\begin{array}{l}\text { Plasma } \\
\text { PBMCs }\end{array}$ & Schizophrenia & 26 & $0 / 0 \%$ \\
\hline $\begin{array}{l}\text { Iwahashi } \\
\text { et al., } 1997 \\
\end{array}$ & Japan & $\begin{array}{l}\text { Plasma } \\
\text { PBMCs }\end{array}$ & $\begin{array}{l}\text { Schizophrenia } \\
\text { Control }\end{array}$ & $\begin{array}{l}67 \\
31\end{array}$ & $\begin{array}{l}6 / 8.9 \% \\
1 / 3.2 \%\end{array}$ \\
\hline \begin{tabular}{|l|} 
Salvatore \\
et al., 1997 \\
\end{tabular} & USA, Europe & Brain & Schizophrenia & 17 & $9 / 53 \%$ \\
\hline $\begin{array}{l}\text { Haga } \\
\text { et al., } 1997\end{array}$ & Japan & Brain & $\begin{array}{l}\text { Schizophrenia } \\
\text { Control }\end{array}$ & $\begin{array}{l}9 \\
31\end{array}$ & $\begin{array}{l}3 / 33.3 \% \\
2 / 6.5 \%\end{array}$ \\
\hline $\begin{array}{l}\text { Iwata } \\
\text { et al., } 1998\end{array}$ & Japan & $\begin{array}{l}\text { Plasma } \\
\text { PBMCs }\end{array}$ & $\begin{array}{l}\text { Schizophrenia } \\
\text { Control }\end{array}$ & $\begin{array}{l}77 \\
84\end{array}$ & $\begin{array}{l}3 / 4 \% \\
2 / 2 \%\end{array}$ \\
\hline $\begin{array}{l}\text { Czygan } \\
\text { et al., } 1999\end{array}$ & Germany & $\begin{array}{l}\text { Plasma } \\
\text { PBMCs }\end{array}$ & $\begin{array}{l}\text { Schizophrenia } \\
\text { Control }\end{array}$ & $\begin{array}{l}13 \\
52\end{array}$ & $\begin{array}{l}0 / 0 \% \\
0 / 0 \%\end{array}$ \\
\hline $\begin{array}{l}\text { Kim } \\
\text { et al., } 1999 \\
\end{array}$ & Korea & $\begin{array}{l}\text { Plasma } \\
\text { PBMCs }\end{array}$ & Schizophrenia & 39 & $0 / 0 \%$ \\
\hline $\begin{array}{l}\text { Chen } \\
\text { et al., 1999b }\end{array}$ & Taiwan & $\begin{array}{l}\text { Plasma } \\
\text { PBMCs }\end{array}$ & $\begin{array}{l}\text { Schizophrenia } \\
\text { Mental health workers } \\
\text { Control }\end{array}$ & $\begin{array}{l}74 \\
45 \\
69 \\
\end{array}$ & $\begin{array}{l}10 / 14 \% \\
7 / 15 \% \\
1 / 1,4 \%\end{array}$ \\
\hline $\begin{array}{l}\text { Nakamura } \\
\text { et al., } 2000\end{array}$ & Japan & Brain & $\begin{array}{l}\text { Schizophrenia } \\
\text { Control }\end{array}$ & $\begin{array}{l}4 \\
2 \\
\end{array}$ & $\begin{array}{l}2 / 50 \% \\
0 / 0 \% \\
\end{array}$ \\
\hline $\begin{array}{l}\text { Tsuji } \\
\text { et al., } 2000\end{array}$ & Japan & $\begin{array}{l}\text { Plasma } \\
\text { PBMCs }\end{array}$ & $\begin{array}{l}\text { Schizophrenia } \\
\text { Control }\end{array}$ & $\begin{array}{l}229 \\
229\end{array}$ & $\begin{array}{l}4 / 1.8 \% \\
1 / 0.6 \% \\
\end{array}$ \\
\hline $\begin{array}{l}\text { Fukuda } \\
\text { et al., } 2001\end{array}$ & Japan & $\begin{array}{l}\text { Plasma } \\
\text { PBMCs } \\
\end{array}$ & $\begin{array}{l}\text { Schizophrenia } \\
\text { Control }\end{array}$ & $\begin{array}{l}45 \\
45 \\
\end{array}$ & $\begin{array}{l}0 / 0 \% \\
0 / 0 \% \\
\end{array}$ \\
\hline $\begin{array}{l}\text { Kim } \\
\text { et al., } 2003\end{array}$ & Korea & Serum & Schizophrenia & 62 & $0 / 0 \%$ \\
\hline $\begin{array}{l}\text { Nunes } \\
\text { et al., } 2008\end{array}$ & Brazil & $\begin{array}{l}\text { Plasma } \\
\text { PBMCs }\end{array}$ & $\begin{array}{l}\text { Schizophrenia, } \\
\text { schizoaffective disorders } \\
\text { Relatives with psychiatric } \\
\text { disorders } \\
\text { Relatives without } \\
\text { psychiatric disorders } \\
\text { Control }\end{array}$ & $\begin{array}{l}27 \\
24 \\
20 \\
27\end{array}$ & $\begin{array}{l}12 / 44.4 \% \\
9 / 37.5 \% \\
10 / 50 \% \\
4 / 14.8 \%\end{array}$ \\
\hline $\begin{array}{l}\mathrm{Na} \\
\text { et al., } 2009\end{array}$ & Korea & $\begin{array}{l}\text { Plasma } \\
\text { PBMCs }\end{array}$ & $\begin{array}{l}\text { Schizophrenia } \\
\text { Control }\end{array}$ & $\begin{array}{l}60 \\
60\end{array}$ & $\begin{array}{l}0 / 0 \% \\
0 / 0 \%\end{array}$ \\
\hline $\begin{array}{l}\text { Karakose } \\
\text { et al., } 2011\end{array}$ & Turkey & $\begin{array}{l}\text { Plasma } \\
\text { PBMCs }\end{array}$ & $\begin{array}{l}\text { Schizophrenia } \\
\text { Control }\end{array}$ & $\begin{array}{l}207 \\
137\end{array}$ & $\begin{array}{l}0 / 0 \% \\
0 / 0 \%\end{array}$ \\
\hline
\end{tabular}

Table 5. Studies that detected BDV RNA in patients with schizophrenic disorders 


\begin{tabular}{|c|c|c|c|c|c|c|}
\hline Authors & Country & Method/marker & Sample & Diagnosis & Total no. & $\begin{array}{l}\text { No. and \% of } \\
\text { positives }\end{array}$ \\
\hline $\begin{array}{l}\text { Amsterdam } \\
\text { et al., } 1985\end{array}$ & USA & IFA/Ab & Serum & $\begin{array}{l}\text { Unipolar and } \\
\text { bipolar } \\
\text { depression } \\
\text { Control }\end{array}$ & $\begin{array}{l}265 \\
105\end{array}$ & $\begin{array}{l}12 / 4.5 \% \\
0 / 0 \%\end{array}$ \\
\hline \begin{tabular}{|l} 
Bode \\
et al., 1993
\end{tabular} & Germany & IFA/Ab & Serum & $\begin{array}{l}\text { Major depression } \\
\text { Neurotic } \\
\text { depression, } \\
\text { dysthymia }\end{array}$ & $?$ & $\begin{array}{l}? / 30 \% \\
? / 8 \%\end{array}$ \\
\hline $\begin{array}{l}\text { Fu } \\
\text { et al., } 1993\end{array}$ & Japan & $\mathrm{WB} / \mathrm{Ab}$ & Serum & $\begin{array}{l}\text { Affective disorders } \\
\text { Control }\end{array}$ & $\begin{array}{l}138 \\
117\end{array}$ & $\begin{array}{l}9 / 6.5 \% \\
1 / 0.9 \%\end{array}$ \\
\hline $\begin{array}{l}\text { Sauder } \\
\text { et al., } 1996\end{array}$ & Germany & $\mathrm{WB} / \mathrm{Ab}$ & Serum & $\begin{array}{l}\text { Affective disorders } \\
\text { Control }\end{array}$ & $\begin{array}{l}52 \\
203\end{array}$ & $\begin{array}{l}6 / 11.5 \% \\
3 / 1.4 \%\end{array}$ \\
\hline $\begin{array}{l}\text { Bode } \\
\text { et al., } 1994\end{array}$ & Germany & RT-PCR/RNA & $\begin{array}{l}\text { Plasma } \\
\text { PBMCs }\end{array}$ & $\begin{array}{l}\text { Depression } \\
\text { Control }\end{array}$ & $\begin{array}{l}3 \\
10 \\
\end{array}$ & $\begin{array}{l}2 / 66 \% \\
0 / 0 \%\end{array}$ \\
\hline $\begin{array}{l}\text { Igata-yi } \\
\text { et al., } 1996\end{array}$ & Japan & RT-PCR/RNA & $\begin{array}{l}\text { Plasma } \\
\text { PBMCs }\end{array}$ & $\begin{array}{l}\text { Depressive } \\
\text { disorders } \\
\text { Control }\end{array}$ & $\begin{array}{l}6 \\
36\end{array}$ & $\begin{array}{l}1 / 16.4 \% \\
0 / 0 \%\end{array}$ \\
\hline $\begin{array}{l}\text { De la Torre } \\
\text { et al., } 1996\end{array}$ & USA & $\begin{array}{l}\text { RT-PCR/RNA, } \\
\mathrm{Ag}\end{array}$ & Brain & $\begin{array}{l}\text { Depressive } \\
\text { disorders }\end{array}$ & 36 & $4 / 11.1 \%$ \\
\hline $\begin{array}{l}\text { Kubo } \\
\text { et al., } 1997\end{array}$ & Japan & IFA/Ab & Plasma & $\begin{array}{l}\text { Mood disorders } \\
\text { Control }\end{array}$ & $\begin{array}{l}123 \\
70\end{array}$ & $\begin{array}{l}0 / 0 \% \\
0 / 0 \%\end{array}$ \\
\hline $\begin{array}{l}\text { Lieb } \\
\text { et al., } 1997\end{array}$ & Germany & RT-PCR/RNA & $\begin{array}{l}\text { Plasma } \\
\text { PBMCs }\end{array}$ & \begin{tabular}{|l} 
Depressive \\
disorders \\
Bipolar disorders
\end{tabular} & $\begin{array}{l}41 \\
10\end{array}$ & $\begin{array}{l}0 / 0 \% \\
0 / 0 \%\end{array}$ \\
\hline $\begin{array}{l}\text { Iwata } \\
\text { et al., } 1998\end{array}$ & Japan & RT-PCR/RNA & $\begin{array}{l}\text { Plasma } \\
\text { PBMCs }\end{array}$ & $\begin{array}{l}\text { Affective disorders } \\
\text { Control }\end{array}$ & $\begin{array}{l}49 \\
84\end{array}$ & $\begin{array}{l}2 / 4 \% \\
2 / 2 \%\end{array}$ \\
\hline $\begin{array}{l}\text { Deuschle } \\
\text { et al., } 1998\end{array}$ & Germany & RT-PCR/RNA & CSF & \begin{tabular}{|l|} 
Recurrent \\
depressive \\
disorders
\end{tabular} & 32 & $3 / 9.4 \%$ \\
\hline $\begin{array}{l}\text { Yamaguchi } \\
\text { et al., } 1999\end{array}$ & Japan & ECLIA/Ab & Serum & $\begin{array}{l}\text { Affective disorders } \\
\text { Control }\end{array}$ & $\begin{array}{l}251 \\
917\end{array}$ & \begin{tabular}{|l|}
$9 / 3.59 \%$ \\
$10 / 1.09 \%$
\end{tabular} \\
\hline $\begin{array}{l}\text { Czygan } \\
\text { et al., } 1999\end{array}$ & Germany & RT-PCR/RNA & Brain & $\begin{array}{l}\text { Affective disorders } \\
\text { Control }\end{array}$ & $\begin{array}{l}11 \\
52\end{array}$ & $\begin{array}{l}0 / 0 \% \\
0 / 0 \%\end{array}$ \\
\hline $\begin{array}{l}\text { Kim } \\
\text { et al., } 1999\end{array}$ & Korea & RT-PCR/RNA & $\begin{array}{l}\text { Plasma } \\
\text { PBMCs }\end{array}$ & $\begin{array}{l}\text { Bipolar disorders } \\
\text { Depressive } \\
\text { disorders } \\
\end{array}$ & $\begin{array}{l}33 \\
9\end{array}$ & $\begin{array}{l}0 / 0 \% \\
0 / 0 \%\end{array}$ \\
\hline $\begin{array}{l}\text { Fukuda } \\
\text { et al., } 2001\end{array}$ & Japan & RT-PCR/RNA & $\begin{array}{l}\text { Plasma } \\
\text { PBMCs }\end{array}$ & $\begin{array}{l}\text { Affective disorders } \\
\text { Control }\end{array}$ & $\begin{array}{l}45 \\
45\end{array}$ & $\begin{array}{l}1 / 2 \% \\
0 / 0 \%\end{array}$ \\
\hline $\begin{array}{l}\text { Fukuda } \\
\text { et al., } 2001\end{array}$ & Japan & $\mathrm{WB} / \mathrm{Ab}$ & Plasma & $\begin{array}{l}\text { Affective disorders } \\
\text { Control }\end{array}$ & $\begin{array}{l}45 \\
45 \\
\end{array}$ & $\begin{array}{l}1 / 2 \% \\
0 / 0 \% \\
\end{array}$ \\
\hline $\begin{array}{l}\text { Terayama } \\
\text { et al., } 2003\end{array}$ & Japan & $\mathrm{WB} / \mathrm{Ab}$ & Serum & $\begin{array}{l}\text { Mood disorders } \\
\text { Control }\end{array}$ & $\begin{array}{l}33 \\
25\end{array}$ & \begin{tabular}{|l|}
$9 / 27.3 \%$ \\
$1 / 4 \%$
\end{tabular} \\
\hline \multirow[t]{3}{*}{\begin{tabular}{|l|} 
Bode \\
et al., 2001
\end{tabular}} & Germany & $\begin{array}{l}\text { ELISA/CIC, Ag } \\
\text { IFA/ } \mathrm{Ab}\end{array}$ & Plasma & Affective disorders & 187 & $\begin{array}{l}62 \% \text { CIC, } 11 \% \\
\mathrm{Ab}, 15 \% \mathrm{Ag}\end{array}$ \\
\hline & & & & & 103 & $\begin{array}{l}52 \% \text { CIC, } 20 \% \\
\mathrm{Ab}, 23 \% \mathrm{Ag}\end{array}$ \\
\hline & & & & Control & 100 & $\begin{array}{l}24 \% \text { CIC, } 2 \% \\
\mathrm{Ab}, 0 \mathrm{Ag}\end{array}$ \\
\hline
\end{tabular}




\begin{tabular}{|c|c|c|c|c|c|c|}
\hline Authors & Country & Method/marker & Sample & Diagnosis & Total no. & $\begin{array}{l}\text { No. and } \% \text { of } \\
\text { positives }\end{array}$ \\
\hline \multirow{3}{*}{$\begin{array}{l}\text { Bode } \\
\text { et al., } 2001\end{array}$} & \multirow[t]{3}{*}{ Germany } & \multirow{3}{*}{$\begin{array}{l}\text { ELISA/CIC, Ag } \\
\text { IFA/Ab }\end{array}$} & \multirow{3}{*}{ Plasma } & Severe depression & 28 & $90 \%$ CIC \\
\hline & & & & Mild depression & 28 & $90 \% \mathrm{CIC}$ \\
\hline & & & & Control & 65 & $32 \%$ CIC \\
\hline $\begin{array}{l}\text { Matsunaga } \\
\text { et al., } 2005\end{array}$ & Japan & WB, RIA/Ab & Serum & $\begin{array}{l}\text { Mood disorders } \\
\text { Control }\end{array}$ & $\begin{array}{l}80 \\
41\end{array}$ & $\begin{array}{l}11 / 13.75 \% \\
2 / 1 \%\end{array}$ \\
\hline $\begin{array}{l}\mathrm{Na} \\
\text { et al., } 2009\end{array}$ & Korea & $\begin{array}{l}\text { RT-PCR/RNA } \\
\text { IFA/Ab }\end{array}$ & $\begin{array}{l}\text { Plasma } \\
\text { PBMCs }\end{array}$ & $\begin{array}{l}\text { Affective disorders } \\
\text { Control }\end{array}$ & $\begin{array}{l}138 \\
60\end{array}$ & $\begin{array}{l}0 / 0 \% \\
0 / 0 \%\end{array}$ \\
\hline
\end{tabular}

Table 6. Studies that detected BDV infection in patients with affective disorders

\subsection{Borna disease virus infection and neurotic disorders}

Only a few studies reported BDV positivity in neurotic disorders: we identified 10 studies and 7 of them examined patients with chronic fatigue syndrome. Six studies detected BDV $\mathrm{Ab}$, two detected BDV RNA and one detected both RNA and Ab markers. The rate of BDV positivity ranged from $0 \%$ to $34 \%$ in psychiatric patients and between $0 \%$ and $5.9 \%$ in healthy controls (see Table 7).

\begin{tabular}{|c|c|c|c|c|c|c|}
\hline Authors & Country & Method/marker & Sample & Diagnosis & Total No & $\begin{array}{l}\text { No and } \% \text { of } \\
\text { positive }\end{array}$ \\
\hline $\begin{array}{l}\text { Sauder } \\
\text { et al., } 1996\end{array}$ & Germany & $\mathrm{WB} / \mathrm{Ab}$ & Serum & $\begin{array}{l}\text { Neurotic, } \\
\text { personality } \\
\text { disorders } \\
\text { Control }\end{array}$ & $\begin{array}{l}54 \\
203\end{array}$ & $\begin{array}{l}8 / 14.8 \% \\
3 / 1.4 \%\end{array}$ \\
\hline $\begin{array}{l}\text { Bode } \\
\text { et al., } 1994\end{array}$ & Germany & RT-PCR/RNA & Serum & $\begin{array}{l}\text { Panic disorder } \\
\text { OCD } \\
\text { Control }\end{array}$ & $\begin{array}{l}1 \\
1 \\
10\end{array}$ & $\begin{array}{l}0 / 0 \% \\
1 / 100 \% \\
0 / 0 \%\end{array}$ \\
\hline $\begin{array}{l}\text { Nowotny \& } \\
\text { Windhaber, } \\
1997\end{array}$ & Germany & $?$ & Serum & $\begin{array}{l}\text { Panic disorders } \\
\text { Control }\end{array}$ & $\begin{array}{l}55 \\
34\end{array}$ & $\begin{array}{l}4 / 7.3 \% \\
2 / 5.9 \%\end{array}$ \\
\hline $\begin{array}{l}\text { Bode } \\
\text { et al., } 1992\end{array}$ & $\begin{array}{l}\text { Germany, } \\
\text { USA }\end{array}$ & IFA/Ab & Serum & $\begin{array}{l}\text { Chronic fatigue } \\
\text { syndrome }\end{array}$ & 50 & $0 / 0 \%$ \\
\hline $\begin{array}{l}\text { Nakaya } \\
\text { et al., } 1996\end{array}$ & Japan & RT-PCR/RNA & $\begin{array}{l}\text { Plasma } \\
\text { PBMCs }\end{array}$ & $\begin{array}{l}\text { Chronic fatigue } \\
\text { syndrome }\end{array}$ & 25 & $8 / 32 \%$ \\
\hline $\begin{array}{l}\text { Kitani } \\
\text { et al., } 1996\end{array}$ & Japan & ELISA/Ab & Serum & $\begin{array}{l}\text { Chronic fatigue } \\
\text { syndrome }\end{array}$ & 89 & $30 / 34 \%$ \\
\hline $\begin{array}{l}\text { Gow } \\
\text { et al., } 1997\end{array}$ & UK & $\mathrm{WB} / \mathrm{Ab}$ & Serum & $\begin{array}{l}\text { Chronic fatigue } \\
\text { syndrome } \\
\text { Control }\end{array}$ & $\begin{array}{l}21 \\
13\end{array}$ & $\begin{array}{l}2 / 10 \% \\
0 / 0 \%\end{array}$ \\
\hline $\begin{array}{l}\text { Evengard } \\
\text { et al., } 1999\end{array}$ & Sweden & $\begin{array}{l}\text { WB, ELISA/Ab } \\
\text { RT-PCR/RNA }\end{array}$ & $\begin{array}{l}\text { Serum } \\
\text { Plasma } \\
\text { PBMCs }\end{array}$ & $\begin{array}{l}\text { Chronic fatigue } \\
\text { syndrome }\end{array}$ & 18 & $0 / 0 \%$ \\
\hline $\begin{array}{l}\text { Yamaguchi } \\
\text { et al., } 1999\end{array}$ & Japan & ECLIA/Ab & Serum & $\begin{array}{l}\text { Chronic fatigue } \\
\text { syndrome } \\
\text { Control }\end{array}$ & $\begin{array}{l}75 \\
917\end{array}$ & $\begin{array}{l}0 / 0 \% \\
10 / 1.09 \%\end{array}$ \\
\hline $\begin{array}{l}\mathrm{Li} \\
\text { et al., } 2003\end{array}$ & China & $\mathrm{WB} / \mathrm{Ab}$ & Plasma & $\begin{array}{l}\text { Chronic fatigue } \\
\text { syndrome } \\
\text { Control }\end{array}$ & $\begin{array}{l}61 \\
73\end{array}$ & $\begin{array}{l}7 / 11.8 \% \\
0 / 0 \%\end{array}$ \\
\hline
\end{tabular}

Table 7. Studies that detected BDV infection in patients with anxiety disorders and OCD 


\subsection{Borna disease virus and unspecified psychiatric disorders}

Several studies examined psychiatric patients with various diagnoses and it was not possible to divide these groups according the diagnosis. We found 17 studies that detected BDV infection in unspecified psychiatric (or neuropsychiatric) patients, 5 studies that detected $\mathrm{BDV} \mathrm{Ab}, 1$ study that detected $\mathrm{Ab}$ and $\mathrm{Ag}, 1$ that only detected $\mathrm{Ag}, 7$ studies that detected BDV RNA, 2 that detected BDV CIC and 1 study detected BDV Ab and RNA. The rate of BDV positivity ranged between $0 \%$ and $66.7 \%$ in psychiatric patients and between $0 \%$ and $37.3 \%$ in healthy individuals (see Table 8 ).

\begin{tabular}{|c|c|c|c|c|c|c|}
\hline Authors & Country & Method/marker & Sample & Diagnosis & Total No & $\begin{array}{l}\text { No and } \% \text { of } \\
\text { positive }\end{array}$ \\
\hline $\begin{array}{l}\text { Rott } \\
\text { et al., } 1985\end{array}$ & $\begin{array}{l}\text { Germany, } \\
\text { USA }\end{array}$ & IFA/Ab & Serum & $\begin{array}{l}\text { Psychiatric patients } \\
\text { Control }\end{array}$ & $\begin{array}{l}979 \\
200 \\
\end{array}$ & $\begin{array}{l}16 / 1.6 \% \\
0 / 0 \% \\
\end{array}$ \\
\hline $\begin{array}{l}\text { Bode } \\
\text { et al., } 1992\end{array}$ & $\begin{array}{l}\text { Europe, } \\
\text { USA, Africa }\end{array}$ & $\begin{array}{l}\text { IFA, } \\
\text { immunoprecipit } \\
\text { ation/ } \mathrm{Ab}, \mathrm{Ag}\end{array}$ & Serum & $\begin{array}{l}\text { Chronic diseases of } \\
\text { the brain, immune } \\
\text { system, infection } \\
\text { (HIV, parasitosis) } \\
\text { Control }\end{array}$ & $\begin{array}{l}\text { Total } \\
\text { number } \\
3000\end{array}$ & $? / 13-14 \%$ \\
\hline $\begin{array}{l}\text { Bode } \\
\text { et al., } 1993\end{array}$ & Germany & IFA/Ab & Serum & $\begin{array}{l}\text { Psychiatric patients } \\
\text { (screening) }\end{array}$ & 70 & $1-3 / 2-4 \%$ \\
\hline $\begin{array}{l}\text { Bode } \\
\text { et al., } 1993\end{array}$ & Germany & IFA/Ab & Serum & $\begin{array}{l}\text { Psychiatric patients } \\
\text { (follow-up test) }\end{array}$ & 70 & $14 / 20 \%$ \\
\hline $\begin{array}{l}\text { Kishi } \\
\text { et al., } 1995\end{array}$ & Japan & WB, ELISA/Ab & Serum & Control & 100 & $1 / 1 \%$ \\
\hline $\begin{array}{l}\text { Kishi } \\
\text { et al., } 1995\end{array}$ & Japan & RT-PCT/RNA & $\begin{array}{l}\text { Plasma } \\
\text { PBMCs }\end{array}$ & $\begin{array}{l}\text { Psychiatric patients } \\
\text { Control }\end{array}$ & $\begin{array}{l}60 \\
100 \\
72 \\
\end{array}$ & \begin{tabular}{|l|}
$22 / 37 \%$ \\
$5 / 5 \%$ \\
$3 / 4.2 \%$ \\
\end{tabular} \\
\hline $\begin{array}{l}\text { Bode } \\
\text { et al., } 1996\end{array}$ & Germany & $\mathrm{Ag}$ & $\begin{array}{l}\text { Plasma } \\
\text { PBMCs }\end{array}$ & $\begin{array}{l}\text { Recurrent } \\
\text { depressive and } \\
\text { bipolar disorders } \\
\text { Other depressive } \\
\text { and anxiety } \\
\text { disorders } \\
\text { Psychotic disorders }\end{array}$ & $\begin{array}{l}10 \\
11 \\
11\end{array}$ & $\begin{array}{l}53 \text { samples } \\
\text { (collected in a } \\
\text { week), } 20 \\
\text { positive }\end{array}$ \\
\hline $\begin{array}{l}\text { Sauder } \\
\text { et al., } 1996\end{array}$ & Germany & RT-PCR/RNA & $\begin{array}{l}\text { Plasma } \\
\text { PBMCs }\end{array}$ & $\begin{array}{l}\text { Psychiatric } \\
\text { disorders } \\
\text { Control }\end{array}$ & $\begin{array}{l}26 \\
23\end{array}$ & $\begin{array}{l}13 / 50 \% \\
0 / 0 \%\end{array}$ \\
\hline $\begin{array}{l}\text { Kubo } \\
\text { et al., } 1997\end{array}$ & Japan & RT-PCR/RNA & $\begin{array}{l}\text { Plasma } \\
\text { PBMCs }\end{array}$ & $\begin{array}{l}\text { Psychiatric patients } \\
\text { Control }\end{array}$ & $\begin{array}{l}106 \\
12\end{array}$ & $\begin{array}{l}0.2 \% \\
0 / 0 \%\end{array}$ \\
\hline $\begin{array}{l}\text { Salvatore } \\
\text { et al., } 1997\end{array}$ & $\begin{array}{l}\text { USA, } \\
\text { Europe }\end{array}$ & RT-PCR/RNA & Brain & $\begin{array}{l}\text { Neuropsychiatric } \\
\text { disorders }\end{array}$ & 75 & $11 / 14.7 \%$ \\
\hline $\begin{array}{l}\text { Lieb } \\
\text { et al., } 1997\end{array}$ & Germany & RT-PCR/RNA & $\begin{array}{l}\text { Plasma } \\
\text { PBMCs }\end{array}$ & $\begin{array}{l}\text { Psychiatric } \\
\text { disorders }\end{array}$ & 159 & $0 / 0 \%$ \\
\hline $\begin{array}{l}\text { Czygan } \\
\text { et al., } 1999\end{array}$ & Germany & RT-PCR/RNS & Brain & $\begin{array}{l}\text { Neuropsychiatric } \\
\text { disorders } \\
\text { Control }\end{array}$ & $\begin{array}{l}86 \\
52\end{array}$ & $\begin{array}{l}0 / 0 \% \\
0 / 0 \%\end{array}$ \\
\hline $\begin{array}{l}\text { Vahlenkamp } \\
\text { et al., } 2000\end{array}$ & Germany & RT-PCR/RNA & $\begin{array}{l}\text { Plasma } \\
\text { PBMCs }\end{array}$ & $\begin{array}{l}\text { Psychiatric patients } \\
\text { Control }\end{array}$ & $\begin{array}{l}27 \\
13\end{array}$ & $\begin{array}{l}10 / 37 \% \\
2 / 15.4 \%\end{array}$ \\
\hline $\begin{array}{l}\text { Rybakowski } \\
\text { et al., } 2001\end{array}$ & Poland & ECLIA/Ab & Serum & Psychiatric patients & 946 & $23 / 2.4 \%$ \\
\hline
\end{tabular}




\begin{tabular}{|c|c|c|c|c|c|c|}
\hline Authors & Country & Method/marker & Sample & Diagnosis & Total No & $\begin{array}{l}\text { No and \% of } \\
\text { positive }\end{array}$ \\
\hline $\begin{array}{l}\text { Rackova } \\
\text { et al., } 2003\end{array}$ & $\begin{array}{l}\text { Czech } \\
\text { Republic }\end{array}$ & ELISA/CIC & Plasma & $\begin{array}{l}\text { Affective and } \\
\text { schizophrenic } \\
\text { disorders } \\
\text { Control }\end{array}$ & 126 & $12 / 26.1 \%$ \\
\hline $\begin{array}{l}\text { Miranda } \\
\text { et al., } 2006\end{array}$ & Brazil & RT-PCR/RNA & $\begin{array}{l}\text { Plasma } \\
\text { PBMCs }\end{array}$ & $\begin{array}{l}\text { Schizophrenia and } \\
\text { affective disorders } \\
\text { Control }\end{array}$ & $\begin{array}{l}30 \\
30\end{array}$ & $\begin{array}{l}10 / 33.3 \% \\
4 / 13.3 \%\end{array}$ \\
\hline $\begin{array}{l}\text { Matsunaga } \\
\text { et al., } 2008\end{array}$ & Japan & RIA/Ab & Serum & $\begin{array}{l}\text { Psychiatric patients } \\
\text { Control }\end{array}$ & $\begin{array}{l}304 \\
378\end{array}$ & $\begin{array}{l}\text { No significant } \\
\text { difference }\end{array}$ \\
\hline $\begin{array}{l}\text { Rackova } \\
\text { et al., } 2009\end{array}$ & $\begin{array}{l}\text { Czech } \\
\text { Republic }\end{array}$ & ELISA/CIC & Plasma & $\begin{array}{l}\text { Affective and } \\
\text { schizophrenic } \\
\text { disorders } \\
\text { Control } \\
\end{array}$ & 126 & $\begin{array}{l}26 / 66.7 \% \\
28 / 22.2 \% \\
\end{array}$ \\
\hline $\begin{array}{l}\text { Karakose } \\
\text { et al., } 2011\end{array}$ & Turkey & ELISA/Ab & Serum & $\begin{array}{l}\text { Psychiatric } \\
\text { disorders } \\
\text { Control }\end{array}$ & $\begin{array}{l}131 \\
137\end{array}$ & $\begin{array}{l}17 / 12.98 \% \\
19 / 13.86 \%\end{array}$ \\
\hline $\begin{array}{l}\text { Karakose } \\
\text { et al., } 2011\end{array}$ & Turkey & RT-PCR/RNA & $\begin{array}{l}\text { Plasma } \\
\text { PBMCs }\end{array}$ & $\begin{array}{l}\text { Psychiatric } \\
\text { disorders } \\
\text { Control }\end{array}$ & $\begin{array}{l}131 \\
137\end{array}$ & $\begin{array}{l}0 / 0 \% \\
0 / 0 \%\end{array}$ \\
\hline
\end{tabular}

Table 8. Studies that detected BDV infection in psychiatric patients

\subsection{Borna diasease virus and other disorders}

The influence of BDV infection on other disorders was also studied, particularly on neurological and infectious diseases. Prudlo and colleagues did not find any increase in $\mathrm{BDV} \mathrm{Ab}$ positivity in neurologic patients (with amyotrophic lateral sclerosis) compared to surgical patients (Prudlo et al., 2002). Li and colleagues detected BDV RNA in patients with viral encephalitis, but no BDV positivity was found in other neurological disorders (Li et al., 2009; Salvatore et al., 1997). Flower and colleagues reported higher rates of BDV CIC positivity in multitransfused patients (Flower et al., 2008), and BDV RNA and Ag were detected in the cerebrospinal fluid of patients with multiple sclerosis (Deuschle et al., 1998). A higher rate of BDV positivity was not detected in patients with epilepsy (Czygan et al., 1999; Hofer et al., 2006) or Parkinson's disease (Haga et al., 1997). Several studies detected higher rates of BDV infection positivity in HIV-positive patients (Auwanit et al., 1996; Bode et al., 1992; Cotto et al., 2003) but not in therapeutically immunosuppressed patients (Cotto et al., 2003).

\section{Conclusions}

The Borna disease virus is a neurotropic RNA virus belonging to the family Bornaviridae, order Mononegavirales, which has a high affinity for the central nervous system, especially for limbic structures. The Borna disease virus causes an infection in birds and mammals including humans. Some infected animals develop symptoms which are very similar to human psychiatric disorders (cognitive impairment, behavioural changes, changes in social behaviour, appetite, sleeping...). Because of this similarity BDV has begun to be associated with several psychiatric disorders, especially with mood and psychotic disorders. The association of BDV and psychiatric disorders is explained by the viro-psycho- 
immunological disease model. A BDV persistent infection of the central nervous system is activated by changes in the immune system, an activated BDV infection influences neurotransmitter functions and contributes to the onset of psychiatric disorders in vulnerable individuals (with a genetic predisposition).

In the 1980s the presence of a BDV infection was found in patients with neuropsychiatric disorders. Since the 1980s many studies have detected a BDV infection in patients with psychiatric disorders (the majority of them tested BDV positive in affective disorders and schizophrenia) and in patients with neurological disorders, HIV infection and others. The positivity of a BDV infection ranges from negative results to very high positivity rates, more than $90 \%$ in patients with affective disorders in comparison with BDV positivity between $0 \%-40 \%$ in healthy individuals. The Borna disease virus positivity in psychiatric patients ranges from negative to highly positive. These differences in positivity can be caused by several factors; features of the psychiatric population (age, diagnosis, severity of the psychopathology, immune status), geographical region, differences in specificity and sensitivity of the laboratory methods used and others. The significantly higher rates of BDV positivity were detected in younger individuals, especially in children. Several research groups reported an association between higher BDV positivity and the severity of the psychopathology. The high variability of BDV positivity in humans can be influenced by the laboratory method used. The detection of BDV CIC by ELISA has shown a 10-fold higher incidence of $\mathrm{BDV}$ infection than was estimated for $\mathrm{BDV} \mathrm{Ab}$ positivity by the immunofluorescence method.

\subsection{Arguments supporting the association of BDV infection with psychiatric disorders include}

Characteristics of the Borna disease virus - its ability to infect and spread through the central nervous system, causing persistent infection and its activation, have led to the connection with psychiatric disorders. An experimental BDV infection shows the influence of BDV on neurotransmitter receptors which lead to behavioural changes, cognitive impairment and neurological disturbances.

Many studies have detected the significantly higher BDV positivity in psychiatric patients in comparison with healthy individuals. The Borna disease virus was isolated from PBMCs in plasma, cerebrospinal fluid and brain tissue. Higher levels of BDV antigens and circulating immunocomplexes have been found in acutely depressed patients than in patients with mild depression. Levels of BDV antigens and circulating immunocoplexes correlate with the severity of psychiatric symptoms. Depressed patients who were treated with virostatic medication - amantadine, improved their psychopathology significantly and more quickly. The improvement of depression symptoms correlates with the decrease or disappearance of BDV positivity (levels of antigens).

\subsection{Arguments against the BDV role in ethiopathology in psychiatric disorders include}

Many studies have failed to detect BDV infection in psychiatric patients or did not find significant differences in BDV positivity between psychiatric patients and healthy individuals. Some researchers detected high BDV positivity in healthy individuals and considered BDV infection to be a normal part of human life without any influence on health. 
There are reports about the effect of antiviral treatment with amantadine in BDV positive patients with depression disorders. The improvement of depression symptomatology during this treatment could be explained by the antidepressive effect of amantadine. Some studies did not prove the virostatic effect of amantadine in the treatment a BDV infection.

Several studies criticize the unreliability of some laboratory methods, in these studies BDV was not isolated from BDV CIC positive samples.

What can we conclude? The role of BDV in psychiatric disorders is still unclear. But very probably this infection can be involved in the onset and the course of psychiatric disorders in a determinate subpopulation of psychiatric patients. German and Italian researchers examined the presence of BDV infection in children. These studies are crucial to obtaining information about the possible influence of neurotropic viruses on brain development. A BDV infection in early life can contribute to the onset of psychiatric disorders in adults in predisposed individuals.

For future research, which is important for answering still unclear questions about the Borna disease virus we need more and larger studies testing comparable patient groups and using comparable laboratory methods. We are also missing more double-blind studies with amantadine in BDV positive psychiatric patients. Studies testing for a BDV infection from childhood to adulthood are necessary to answer the question: What is first?: BDV infection and secondly the development of psychiatric disorders or first psychiatric disorders which secondarily leads to several changes in the immune system and then the activation of the BDV infection.

\section{References}

Adinolfi, L.E., Utili, R., Tonziello, A., \& Ruggiero, G.(2003). Effects of alpha interferon induction plus ribavirin with or without amantadine in the treatment of interferon non-responsive chronic hepatitis C: a randomised trial. Gut, Vol.52, No.5, (May 2003), pp. 701-705, ISSN 0017-5749.

Amsterdam, J.D., Winokur, A., Dyson, W., Herzog, S., Gonzales, S., Rott, R., \& Koprowski, H. (1985). Borna disease virus. A possible etiologic factor in human affective disorders? Arch Gen Psychiatry, Vol.42, No.11, (November 1985), pp. 1093-1096, ISSN 0003-990X.

Auwanit, W., Ayuthaya, P.I., Nakaya, T., Fujiwara, S., Kurata, T., Yamanishi, K., \& Ikuta, K. (1996). Unusually high seroprevalence of Borna disease virus in clade $\mathrm{E}$ human immunodeficiency virus type 1-infected patients with sexually transmitted diseases in Thailand. Clin Diagn Lab Imunol, Vol.3, No.5, (September 1996), pp. 590-593, ISSN 1556-6811.

Bechter, K., Herzog, S., Schreiner, V., Brinkmeier, H., Aulkemeyer, P., Weber, F., Wollinsky, K.H., \& Schuttler, R. (2000). Borna disease virus-related therapy-resistant depression improved after cerebrospinal fluid filtration. J Psychiatr Res, Vol.34, No.6, (November-December 2000), pp. 393-396, ISSN 0022-3956.

Berg, M., Johansson, M., Montell, H., \& Berg, A.L. (2001). Wild birds as possible natural reservoir of Borna disease virus. Epidemiol Infect, Vol.127, No.1, (August 2001), pp. 173-178. ISSN 1469-4409.

Billaud, J.N., Ly, C., Phillips, T.R., \& Torre, J.C. (2000). Borna Disease Virus Persistence Causes Inhibition of Glutamate Uptake by Feline Primary Cortical Astrocytes. J 
Virol, Vol.74, No.22, (November 2000), pp. 10438-10446, ISSN 1098-5514, ISSN 1474-547X.

Bode, L., Dietrich, D.E., Detlef, E., Stoyloff, R., Emrich, H.M., \& Ludwig, H. (1997). Amantadine and human Borna disease virus in vitro and in vivo in an infected patient with bipolar depression. Lancet. Vol.349, No.9046, (January 1997), pp. 178179, ISSN 1474-547X.

Bode, L., Durrwald, R., Rantam, F.A., Ferszt, R., \& Ludwig, H. (1996). First isolates of infectious human Borna disease virus from patients with mood disorders. Mol Psychiatry, Vol.1, No.3, (July 1996), pp. 200-212, ISSN 1359- 4184.

Bode, L., Ferszt, R., \& Czech, G. (1993). Borna disease virus infection and affective disorders in man. Arch Virol Suppl, Vol.7, pp. 159-167, ISSN 1432-8798.

Bode, L., Komaroff, A.L., \& Ludwig, H. (1992). No serologic evidence of Borna disease virus in patients with chronic fatigue syndrome. Clin Infect Dis, Vol.15, No.6, (December 1992), pp. 1049, ISSN 1537-6591.

Bode, L., Reckwald, P., Severus, W.E., Stoyloff, R., Ferszt, R., Dietrich, D.E., \& Ludwig, H. (2001). Borna disease virus- specific circulating immune complexes, antigenemia, and free antibodies-the key marker triplet determining infection and prevailing in severe mood disorders. Mol Psychiatry, Vol.6, No.4, (July 2001), pp. 481-491, ISSN 1359-4184.

Bode, L., Riegel, S., Lange, W., \& Ludwig, H. (1992). Human infections of Borna disease virus: seroprevalence in patiens with chronic diseases and healthy individuals. J Med Virol, Vol.36, No.4, (April 1992), pp. 309-315, ISSN 1096- 9071.

Bode, L., Stienbach, F., \& Ludwig, H. (1994). A novel marker for Borna disease virus infection. Lancet, Vol.343, No.8892, (January 1994), pp. 297-298, ISSN 1474-547X.

Brenner, M., Haass, A., Jacobi, P., \& Schimrigk, K. (1989). Amantadine sulphate in treating Parkinsonś disease: clinical effects, psychometric tests and serum concentrations. J Neurol, Vol.236, No.3, (March 1989), pp. 153-156, ISSN 1432-1459.

Briese, T., de la Torre, J.C., Lewis. A., Ludwig, H., \& Lipkin, W.I. (1992). Borna disease virus, a negative-strand RNA virus, transcribes in the nucleus of infected cells. Proc Natl Acad Sci USA, Vol.89, No.23, (December 1992), pp. 11486-11489, ISSN 1091-6490.

Carbone, K.M., Duchala, C.S., Griffin, J.W., Kincaid, A.L., \& Narayan, O. (1987). Pathogenesis of Borna disease in rats: evidence that intra-axonal spread is the major route for virus dissemination and the determinant for disease incubation. J Virol, Vol.61, No.11, (November 1987), pp. 3431-3440, ISSN 1098-5514.

Chen, Ch., Chiu, Y.L., Shaw, C.K., Tsai, M.T., Hwang, A.L., \& Hsiao, K.J. (1999a). High seroprevalence of Borna virus infection in schizophrenic patients, family members and mental health workers in Taiwan. Mol Psychiatry, Vol.4, No.1, (January 1999), pp. 33-38, ISSN 1359-4184.

Chen, Ch., Chiu, Y.L., Shaw, C.K., Tsai, M.T., Hwang, A.L., \& Hsiao, K.J. (1999b). Detection of Borna disease virus RNA from peripheral blood cells in schizofrenic patients and mental health workers. Mol Psychiatry, Vol.4, No.6, (November 1999), pp. 566571, ISSN 1359-4184.

Cotto, E., Neau, D., Cransac-Neau, M., Auriacombe, M., Pellegrin, J.L., Ragnaud, J.M., Fillet, A.M., Belnard, M., Fleury, H., \& Lafon, M.E. (2003). Borna Disease Virus RNA in Immunocompromised Patients in Southwestern France. J Clin Microbiol, Vol.41, No.12, (December 2003), pp. 5577-5581, ISSN 1098-660X. 
Cubitt, B., Oldstone, C., Valcarcel, J., \& de la Torre, J.C. (1994). RNA splicing contributes to the generation of mature mRNAs of Borna disease virus, a non-segment negative strand RNA virus. Virus Res, Vol.34, No.1, (October 1994), pp. 69-79, ISSN 01681702.

Czygan, M., Hallensleben, W., Hofer, M., Pollak, S., Sauder, Ch., Bilzer, T., Blumcke, I., Riederer, P., Bogerts, B., Falkai, P., Schwarz, M.J., Masliah, E., Staeheli, P., Hufert, F.T., \& Lieb, K. (1999). Borna Disease Virus in Human Brains with a Rare Form of Hippocampal Degeneration but not in Brains with Common Neuropsychiatric Disorders. J Infect Dis, Vol.180, No.5, (November 1999), pp. 1695-1699, ISSN 00221899.

Dauphin, G., Legay, V., Sailleau, C., Smondack, S., Hammoumi, S., \& Zientara, S. (2001). Evidence of Borna disease virus genome detection in French domestic animals and in foxes (Vulpes vulpes), J Gen Virol, Vol.82, No.9, (September 2001), pp. 21992204, ISSN 1465-2099.

Deuschle, M., Bode, L., Heuser, I., Schmider, J., \& Ludwig, H. (1998). Borna disease virus protien in cerebrospinal fluid of patients with reccurent depression and multiple sclerosis. Lancet, Vol.352, No.9143, (December 1998), pp. 1828-1829, ISSN 1474$547 X$.

Dietrich, D.E., Bode, L., Spannhuth, C.W., Lau, T., Huber, T.J., Brodhun, B., Ludwig, H., \& Emrich, H.M. (2000). Amantadine in depressive patients with Borna disease virus (BDV) infection: an open trial. Bipolar Disord, Vol.2, No.1, (March 2000), pp.65-70, ISSN 1399-5618.

Dietrich, D.E., Schedlowski, M., Bode, L., Ludwig, H., \& Emrich, H.M. (1998). A viropsycho-immunological disease- model of a subtype affective disorder. Pharmacopsychiatry, Vol.31, No.3, (May 1998), pp. 77-82, ISSN 0176- 3679.

Dietz, D.M., Vogel, M.W., Rubin, S.A., Moran, T.H., Carbone, K.M., \& Pletnikov, M.V. (2004). Developmental alterations in serotonergic neurotransmission in Borna disease virus (BDV)-infected rats: a multidisciplinary analysis. J Neurovirol, Vol.10, No.5, (October 2004), pp. 267-277, ISSN 1538-2443.

Durrwald, R., \& Ludwig, H. (1997). Borna Disease Virus (BDV), a (Zoonotic?) Worlwide Pathogen. A Review of the History of the Disease and the Virus Infection with Comprehensive Bibliography. J Vet Med, Vol.44, No.3, (May 1997), pp. 147-184, ISSN 1439-0442.

Evengard, B., Briese, T., Lindh, G., Lee, S., \& Lipkin, W.I. (1999). Absence of evidence of Borna disease virus infection in Swedish patients with chronic fatigue syndrom. J Neurovirol, Vol.5, No.5, (October 1999), pp. 495-499, ISSN 1538-2443.

Ferszt, R., Kuhl, K.P., Bode, L., Severus, E.W., Winzer, B., Berghofer, A., Beelitz, G., Brodhun, B., Muller-Oerlinghausen, B., \& Ludwig, H. (1999). Amantadine revisited: an open trial of amantadinesulfate treatment in chronically depressed patients with Borna disease virus infection. Pharmacopsychiatry, Vol.32, No.4, (July 1999), pp. 142-147, ISSN 0176-3679.

Ferszt, R., Severus, E., Bode, L., Brehm, M., Kuehl, K.P., Berzewski, H., \& Ludwig, H. (1999) Activated Borna disease virus in affective disorders. Pharmacopsychiatry, Vol.32, No.3, (May 1999), pp. 93-98, ISSN 0176-3679.

Feschotte, C. (2010). Borna virus enters the genome. Nature, Vol.463, No.7277, (January 2010), pp. 39-40, ISSN 0028-0836. 
Flower, R.L.P., Kamhieh, S., Mclean, L., Bode, L., Ludwig, H., \& Ward, Ch.M. (2008). Human Borna disease virus infection in Australia: Serological markers of infection in multi-transfused patients. APMIS Suppl, Vol.116, No.124, pp. 89-93, ISSN 16000463.

Fu, Z.F., Amsterdam, J.D., Kao, M., Shankar, V., Koprowski, H., \& Dietzschold, B. (1993). Detection of Borna disease virus-reactive antibodies from patients with affective disorders by western immunoblot technique. J Affect Disord, Vol.27, No.1, (January 1993), pp. 61-68, ISSN 0165-0327.

Fukuda, K., Takahashi, K., Iwata, Y., Mori, N., Gonda, K., Ogawa, T., Osonoe, K., Sato, M., Ogata, S., Horimoto, T., Sawada, T., Tashiro, M., Yamaguchi, K., Niwa, S., \& Shigeta, S. (2001). Immunological and PCR analyses for Borna disease virus in psychiatric patients and blood donors in Japan. J Clin Microbiol, Vol.39, No.2, (February 2001), pp. 419-429, ISSN 1098-660X.

Galabru, J., Saron, M.F., Berg, M., Berg, A.L., Herzog, S., Labie, J., \& Zientara, S. (2000). Borna disease virus antibodies in French horses. Vet Rec, Vol.147, No.25, (December 2000), pp. 721-722, ISSN 0042-4900.

Gonzales-Dunia, D., Sauder, C., \& de la Torre, J.C. (1997). Borna disease virus and brain. Brain Res Bull, Vol.44, pp. 647- 664, ISSN 0361-9230.

Gonzalez-Dunia, D., Watanabe, M., Syan, S., Mallory, M., Masliah, E., \& de la Torre, J.C. (2000). Synaptic pathology in Borna disease virus persistent infection. J Virol, Vol.74, No.8, (April 2000), pp. 3441-3448, ISSN 1098-5514.

Gosztonyi, G., \& Ludwig, H. (1984). Borna disease of horses. An immunohistological and virological study of naturally infected animals. Acta Neuropathol, Vol.64, No.3, pp. 213-221, ISSN 1432-0533.

Gosztonyi, G., \& Ludwig, H. (2001). Interactions of viral proteins with neurotransmitter receptors may protect or destroy neurons. Curr Top Microbiol Immunol, Vol.253, pp. 121-144, ISSN 0070-217X.

Gow, J.W., de la Torre, J.C., Behan, W.M.H., Simpson, K., McGill, M., Dinan, T., \& Behan, P.O. (1997). Borna disease virus in chronic fatigue syndrome. Neurol Infect Epidemiol, Vol.2, pp.63-66, ISSN 1469-4409.

Haga, S., Motoi, Y., \& Ikeda, K. (1997). Borna disease virus and neuropsychiatric disorders. Lancet, Vol.350, No.9077, (June 1997), pp. 592-593, ISSN 1474-547X.

Hagiwara, K., Asakawa, M., Liao, L., Jiang, W., Yan, S., Chai, J., Oku, Y., Ikuta, K., \& Ito, M. (2001). Seroprevalence of Borna disease virus in domestic animals in Xinjiang, China. Vet Microbiol, Vol.80, No.4, (June 2001), pp. 383- 389, ISSN 0378-1135.

Hagiwara, K., Kamitani, W., Takamura, S., Taniyama, H., Nakaya, T., Tanaka, H., Kirisawa, R., Iwai, H., \& Ikuta, K. (2000). Detection of Borna disease virus in a pregnant mare and her fetus. Vet Microbiol, Vol.72, No.3-4, (March 2000), pp. 207-216, ISSN 03781135.

Hájek, T., Pašková, B., Janovská, D., Bahbouh, R., Hájek, P., Libiger, J., \& Höschl, C. (2002). Higher Prevalence of Antibodies to Borrelia Burgdorferi in Psychiatric Patients Than in Healthy Subjects. Am J Psychiatry, Vol.159, No.2, (February 2002), pp. 297-301, ISSN 1535-7228.

Hallensleben, W., \& Staeheli, P. (1999). Inhibition of Borna disease virus multiplication by interferon: cell line differences in susceptibility. Arch Virol, Vol.144, No.6, pp. 1209-1216, ISSN 1432-8798. 
Hatalski, C.G., Lewis, A.J., \& Lipkin, W.I. (1997). Borna Disease. Emer Infect Dis, Vol.3, No.2, (April-June 1997), pp. 129- 135, ISSN 1080-6059.

Hofer, M.J., Schindler, A.R., Ehrensperger, F., Staeheli, P., \& Pagenstecher, A. (2006). Absence of Borna disease virus in the CNS of epilepsy patients. J Clin Virol, Vol.36, No.1, (May 2006), pp. 84-85, ISSN 1386-6532.

Igata, T., Yamaguchi, K., Igata, Y.R., Yoshiki, K., Takemoto, S., Yamasaki, H., Matuoka, M., \& Miyakawa, T. (1998). Dementia and Borna disease virus. Dement Geriatr Cogn Disord, Vol.9, No.1, (January-February 1998), pp. 24-25, ISSN 1420-8008.

Igata-Yi, R., Yamaguchi, K., Yoshiki, K., Takemoto, S., Yamasaki, H., Matsuoka, M., \& Miyakawa, T. (1996). Borna disease virus and the consumption of raw horse meat. Nat Med, Vol.2, No.9, (September 1996), pp. 948-949, ISSN 1078-8955.

Iwahashi, K., Watanabe, M., Nakanuta, K., Suwaki, H., Nakaya, T., Nakanuta, Y., Takahashi, H., \& Ikuta, K. (1998). Borna disease virus infection and negative syndromes in Japanese schizophrenia patiens. Psychiatry Clin Neurosci, Vol.52, No.1, (February 1998), pp. 119, ISSN 1440-1819.

Iwata, Y., Takahashi, K., Peng, X., Fukuda, K., Ohno, K., Ogawa, T., Gonda, K., Mori, N., Niwa, S., \& Shigeta, S. (1998). Detection and sequence analysis of Borna disease virus p24 RNA from peripheral blood mononuclear cells of patients with mood disorders or schizophrenia and of blood donors. J Virol, Vol.72, No.12, (December 1998), pp. 10044-10049, ISSN 1098-5514.

Jordan, I., Briese, T., Averett, D.R., \& Lipkin, W.I. (1999). Inhibition of Borna disease virus replication by ribavirin. J Virol, Vol.73, No.9, (September 1999), pp. 7903-7906, ISSN 1098-5514.

Kampman, K.M., Volpicelli, J.R., Alterman, A.I., Cornish, J., \& O Brien, C.P. (2000). Amantadine in the treatment of cocaine-dependent patients with severe withdrawal symptoms. Am J Psychiatry, Vol.157, No.12, (December 2000), pp. 2052-2054, ISSN 1535-7228.

Kandel, R., \& Hartshorn, K.L. (2001). Prophylaxis and Treatment of Influenza Virus Infection. Biodrugs, Vol.15, No.5, pp. 303-323, ISSN 1173-8804.

Kao, M., Hamir, A.N., Rupprecht, C.E., Fu, Z.F., Shankar, V., Koprowski, H., \& Dietzschold, B. (1993). Detection of antibodies against Borna disease virus in sera and cerebrospinal fluid of horses in the USA. Vet Rec, Vol.132, No.10, (March 1993), pp. 241-244, ISSN 0042-4900.

Karakose, A.R., Yuksel, P., Turan, N., Ziver, T., Saribaş, S., Nihat, A., Balcioglu, I., Aslan, M., Helps, C.R., Yilmaz, H., \& Kocazeybek, B. (2011). Does borna disease virus (BDV) have a role in the etiopathogenesis of schizophrenia? Afr J Microbiol Res, Vol.5, No.9, (May 2011), pp. 1062-1069, ISSN 1996-0808.

Khan, M.A., Yamaguchi, K., Miyata, H., Kazi, A., Kamahora, T., \& Hino, S. (2000). Prevalence of Anti-Borna Disease Virus Antibody in Horses and Their Caretakers in Bangladesh. Yonago Acta Medica, Vol. 43, pp. 59-67, ISSN 0513-5710.

Kim, Y.K., Kim, S.H., Han, C.S., Lee, H.J., Kim, H.S., Yoon, S.C., Kim, D.J., Song, K.J., Maes, M., \& Song, J.W. (2003). Borna disease virus and deficit schizophrenia. Acta Neuropsychiatrica, Vol.15, No.5, (October 2003), pp. 262- 265, ISSN 1601-5215.

Kim, Y.K., Kim, S.H., Choi, S.H., Ko,Y.H., Kim, L., Lee, M.S., Suh, K.Y., Kwak, D.I., Song, K.J., Lee, Y.J., Yanagihara, R., \& Song, J.W. (1999). Failure to demonstrate Borna disease virus genome in peripheral blood mononuclear cells from psychiatric 
patients in Korea. J Neurovirol, Vol.5, No.2, (April 1999), pp. 196-199, ISSN 15382443.

Kishi, M., Nakaya, T., Nakanuta, Y., Kakinuma, M., Takahashi, T.A., Sekiguchi, S., Uchikawa, M., Tadokoro, K., Ikeda, K., \& Ikuta, K. (1995). Prevalence of Borna disease virus RNA in peripheral blood mononuclear cells from blood donnors. Med Microbiol Immunol, Vol.184,No.3, (October 1995), pp. 135-138, ISSN 14321831.

Kishi, M., Nakaya, T., Nakamura, Y., Zhong, Q., Ikeda, K., Senjo, M., Kakinuma, M., Kato, S., \& Ikuta, K. (1995). Demonstration of human Borna disease virus RNA in human peripheral blood mononuclear cells. FEBS Lett, Vol.364, No.3, (May 1995), pp. 293297, ISSN 0014-5793.

Kitani, T., Kuratsune, H., Fuke, I., Nakamura, Y., Nakaya, T., Asahi, S., Tobiume, M., Yamaguti, K., Machii, T., Inagi, R., Yamanishi, K., \& Ikuta, K. (1996). Possible correlation between Borna disease virus infection and Japanese patients with chronic fatigue syndrome. Microbiol Immunol, Vol.40, No.6, pp. 459-462, ISSN 1217-8950.

Kubo, K., Fujiyoshi, T., Yokoyama, M.M., Kamei, K., Richt, J.A., Kitze, B., Herzog, S., Takigawa, M., \& Sonoda, S. (1997). Lack of association of Borna disease virus and human T-cell leukemia virus type 1 infections with psychiatric disorders among Japanese patients. Clin Diagn Lab Immunol, Vol.4, No.2, (March 1997), pp. 189-194, ISSN 1556-679X.

Li, Q., Wang, Z., Zhu, D., Xu, M., Chen, X., Peng, D., Iwata, Y., \& Xie, P. (2009). Detection and analysis of Borna disease virus in Chinese patients with neurologic disorders. Eur J Neurol, Vol.16, No.3, (March 2009), pp. 399-403, ISSN 1468-1331.

Li, Y.J., Wang, D.X., Zhang, F.M., Liu, Z.D., Yang, A.Y., \& Ykuta, K. (2003). Detection of antibody against Borna disease virus-p24 in the plasma of Chinese patients with chronic fatigue syndrome by Western-blot analysis. Zhonghua Shi Yan He Lin Chuang Bing Du Xue Za Zhi, Vol.17, No.4, (December 2003), pp. 330-333, ISSN 1003-9279.

Lieb, K., Hallensleben, W., Czygan, M., Stitz, L., \& Staeheli, P. (1997). No Borna disease virus-specific RNA detected in blood from psychiatric patients in different regions of Germany. Lancet, Vol.350, No.9083, (October 1997), pp. 1002, ISSN 1474-547X.

Ludwig, H., \& Bode, L. (2000). Borna disease virus: new aspects on infection, disease, diagnosis and epidemiology. Rev. Sci. Tech. Off. Int. Epiz, Vol.19, No.1, (April 2000), pp. 259-288, ISSN 0253-1933.

Matsunaga, H., Tanaka, S., Sasao, F., Nishino, Y., Takeda, M., Tomonaga, K., Ikuta, K., \& Amino, N. (2005). Detection by Radioligand Assay of Antibodies against Borna Disease Virus in Patients with Various Psychiatric Disorders. Clin Diagn Lab Immunol, Vol.12, No.5, (May 2005), pp. 671-676, ISSN 1556-679X.

Matsunaga, H., Tanaka, S., Fukumori, A., Tomonaga, K., Ikuta, K., Amino, N., \& Takeda, M. (2008). Isotype analysis of human anti-Borna disease virus antibodies in Japanese psychiatric and general population. J Clin Virol, Vol.43, No.3, (Novembern2008), pp. 317-322, ISSN 1386-6532.

Miranda, H.C., Nunes, S.O.V., Calvo, E.S., Suzart, S., Ivano, E.N., \& Watanabe, M.A.E. (2006). Detection of Borna Disease Virus p24 RNA in peripheral blood cells from 
Brazilian mood and psychotic disorder patients. J Affec Disord, Vol.90, No.1, (January 2006), pp. 43-47, ISSN 0165-0327.

Na, K.S., Tae, S.H., Song, J.W., \& Kim, Y.K. (2009). Failure to detect Borna disease virus antibody and RNA from peripheral blood mononuclear cells of psychiatric patients. Psychiatry Investig, Vol.6, No.4, (December 2009), pp. 306-312, ISSN 17383684.

Nakamura, Y., Takahashi, H., Shoya, Y., Nakaya, T., Watanabe, M., Tomonaga, K., Iwahashi, K., Ameno, K., Momiyama, N., Taniyama, H., Sata, T., Kurata, T., de la Torre, J.C., \& Ikuta, K. (2000). Isolation of Borna disease virus from human brain tissue. J Virol, Vol.74, No.10, (May 2000), pp. 4601-4611, ISSN 1098-5514.

Nakaya, T., Takahashi, H., Nakamura, Y., Asahi, S., Tobiume, M., Kuratsune, H., Kitani, T., Yamanishi, K., \& Ikuta, K. (1996). Demonstration of Borna disease virus RNA in peripheral blood mononuclear cells derived from Japanese patients with chronic fatigue syndrome. FEBS Lett, Vol.378, No.2, (January 1996), pp. 145-149, ISSN 00145793.

Nowotny, N., \& Windhaber, J. (1997). Borna disease virus and neuropsychiatric disorders. Lancet, Vol.350, No.9077, (August 1997), pp. 593, ISSN 1474-547X.

Nunes, S.O.V., Itano, E.N., Amarante, M.K., Reiche, E.M.V., Miranda, H.C., de Oliveria, C.E.C., Matsuo, T., Vargas, H.O., \& Watanabe, M.A.E. (2008). RNA from Borna disease virus in patients with schizophrenia, schizoaffective patients, and their biological relatives. J Clin Lab Anal, Vol.2, No.4, pp. 314-320, ISSN 1098-2825.

Ohlmeier, M.D., Zhang, Y., Bode, L., Sieg, S., Feutl, S., Ludwig, H., Emrich, H.M., \& Dietrich, D.E. (2008). Amantadine reduces mania in borna disease virus-infected nonpsychotic bipolar patients. Pharmacopsychiatry, Vol.41, No.5, (September 2008), pp. 202-203, ISSN 0176-3679.

Okamoto, M., Hagiwara, K., Kamitani, W., Sako, T., Hirayama, K., Kirisawa, R., Tsuji, M., Ishihara, C., Iwai, H., Kobayashi, T., Tomonaga, K., Ikuta, K., \& Taniyama, H. (2003). Experimantal vertical transmission of Borna disease virus in the mouse. Arch Virol, Vol.148, No.8, (August 2003), pp. 1557-1568, ISSN 1432-8798.

Ovanesov, M.V., Moldovan, K., Smith, K., Vogel, M.W., \& Pletnikov. M.V. (2008). Persistent Borna Disease Visrus (BDV) infection activates microglia prior to detectable loss of granule cells in the hippocampus. J Neuroinflammation, Vol.19, No.5, (May 2008), pp.16, ISSN 1742-2094.

Patti, A.M., Vulcano, A., Candelori, E., Donfrancesco, R., Ludwig, H., \& Bode, L. (2008). Borna disease virus infection in Italian children. A potential risk for the developing brain? APMIS Suppl, Vol.116, No.124, pp. 70-73, ISSN 1600-0463.

Pisoni, G., Nativi, D., Bronzo, V., \& Codazza, D. (2007). Sero-epidemiological study of Borna Disease Virus infection in the Italian equine population. Vet Res Commun, Vol.31(Suppl. 1), (August 2007), pp. 245-248, ISSN 1573- 7446.

Pletnikov, M.V., Moran, T.H., \& Carbone, K.M. (2002). Borna disease virus infection of the neonatal rat: developmental brain injury model of autism spectrum disorders. Front Biosci, Vol.1,No.7, (March 2002), pp. 593-607, ISSN 1093-4715.

Pletnikov, M.V., Rubin, S.A., Schwartz, G.J., Carbone, K.M., \& Moran, T.H. (2000). Effects of neonatal rat Borna disease virus (BDV) infection on the postnatal development of the brain monoaminergic systems. Brain Res Dev Brain Res, Vol.119, No.2, (February 2000), pp. 179-185, ISSN 0165-3806. 
Pletnikov, M.V., Rubin, S.A., Vogel, M.W., Moran, T.H., \& Carbone, K.M. (2002). Effects of genetic background on neonatal Borna disease virus infection-induced neurodevelopmental damage part II: neurochemical alterations and responses to pharmacological treatments. Brain Res, Vol.944, No.1-2, (July 2002), pp. 108- 123, ISSN 0006-8993.

Prudlo, J., Fischer, A., Lapple, M., Muller, A., Neubert, K., Gericke, Ch.A., Ludolph, A.C., Grasser, F., \& Sauder, A. (2002). Seroprevalence of Borna disease virus antibodies is not increased in patients with amyotrophic lateral sclerosis. J Neurol, Vol.249, No.10, (October 2002), pp. 1462-1463, ISSN 1432-1456.

Rackova, S., Janu, L., \& Kabickova, H. (2009). Borna disease virus circulating immunocomplex positivity and psychopathology in psychiatric patients in the Czech Republic. Neuroendrocrinol Lett, Vol.30, No.3, pp. 414- 420, ISSN 0172$780 X$.

Rackova, S., Janu, L., \& Kabickova, H. (2010). Borna disease virus (BDV) circulating immunocomplex positivity in addicted patients in the Czech Republic: A prospective cohort analysis. BMC Psychiatry, Vol.10, No.1, 70, (September 2010), ISSN 1471-244X.

Reeves, N.A., Helps, C.R., Gunn-Moore, D.A., Blundell, C., Finnemore, P.L., Pearson, G.R., \& Harbour, D.A. (1998). Natural Borna disease virus infection in cats in the United Kingdom. Vet Rec, Vol.143, No.19, (November 1998), pp. 523-526, ISSN 0042-4900.

Richt, J.A., Grabner, A., \& Herzog, S. (2000). Borna disease in horses. Vet Clin North Am Equine Pract, Vol.16, No.3, (December 2000), pp. 579-595, 0749-0739.

Richt, J.A., Herzog, S., Pyper, J., Clements, J.E., Narayan, O., Bechter, K., \& Rott, R. (1993). Borna disease virus: nature of the ethiologic agence and significance of infection in man. Arch Virol Suppl, Vol.7, pp. 101-109, ISSN 1432- 8798.

Richt, J.A., \& Rott, R. (2001).Borna disease virus: a mystery as an emerging zoonotic pathogen. Vet J, Vol.161, No.1, (January 2001), pp. 24-40, ISSN 1090-0233.

Rott, R., Herzog, S., Fleischer, B., Winokur, A., Amsterdam, J., Dyson, W., \& Koprowski, H. (1985). Detection of serum antibodies to Borna disease virus in patients with psychiatric disorders. Science, Vol.228, No.4700, (May 1985), pp. 755-756, ISSN 1095-9203.

Rybakowski, F., Sawada, T., \& Yamaguchi, K. (2001). Borna disease virus-reactive antibodies and recent-onset psychiatric disorders. Eur Psychiatry, Vol.16, No.3, (April 2001), pp. 191-192, ISSN 0924-9338.

Sauder, C., Muller, A., Cubitt, B., Mayer, J., Steinmetz, J., \& Trabert, W. (1996). Detection of Borna disease virus (BDV) antibodies and BDV RNA in psychiatric patients: evidence for high sequence conservation of human blood-derived BDV RNA. J Virol, Vol.70, No.11, (November 1996), pp. 7713-7724, ISSN 1098-5514.

Sauder, C., \& de la Torre, J.C. (1998). Sensitivity and reproducibility of RT-PCR to detect Borna disease virus (BDV) RNA in blood: implications for BDV epidemiology. J Virol Meth, Vol.71, No.2, (April 1998), pp. 229-245, ISSN 0166- 0934.

Salvatore, M., Morzunov, S., Schwemmle, M., \& Lipkin, W.I. (1997). Borna disease virus in brains of North American and European people with schizophrenia and bipolar disorder. Lancet, Vol.349, No.9068, (June 1997), pp. 1813- 1814, ISSN 1474-547X.

Scholbach, T., \& Bode, L. (2008). Borna disease virus infection in young children. APMIS Suppl, Vol.116, No.124, pp. 83- 88, ISSN 1600-0463. 
Selten, J.P., van Vliet, K., Pleyte, W., Herzog, S., Hoek, H.W., \& van Loon, A.M. (2000). Borna disease virus and schizophrenia in Surinamese immigrants to the Netherlands. Med Microbiol Immunol, Vol.189, No.2, (November 2000), pp. 55-57, ISSN 14321831.

Sierra-Honigmann, A.M., Carbone, K.M., \& Yolken, R.H. (1995). Polymerase chain reaction (PCR) search for viral nucleic acid sequences in schizophrenia. $\mathrm{Br} \mathrm{J}$ Psychiatry,Vol.166, No.1, (January 1995), pp. 55-60, ISSN 1472-1465.

Solbrig, M.V. (2010). Animal models of CNS viral disease: Examples from Borna disease virus models. Interdiscip Perspect Infect Dis, Vol.2010, No.709791, (February 2010), pp.1-6, ISSN 1687-708X.

Solbrig, M.V., \& Koob, G.F. (2003). Neuropharmacological sequelae of persistent CNS viral infections: lessons from Borna Disease Virus. Pharmacol Biochem Behav, Vol.74, No.4, (March 2003), pp. 777-787, ISSN 0097-3057.

Solbrig, M.V., Koob, G.F., Fallon, J.H.\& Lipkin, W.I. (1994). Tardive dyskinetic syndrome in rats infected with Borna disease virus. Neurobiol Dis, Vol.1, No.3, (December 1994), pp.111-119, ISSN 0969-9961.

Solbrig, M.V., Koob, G.F., Fallon, J.H., Reid, S., \& Lipkin, W.I (1996). Prefrontal cortex dysfunction in Borna disease virus (BDV)-infected rats. Biol Psychiatry, Vol.40, No.7, (October 1996), pp. 629-636, ISSN 0006-3223.

Solbrig, M.V., Koob, G.F., Joyce, J.N., \& Lipkin, W.I. (1996). A neural substrate of hyperactivity in Borna disease: changes in brain dopamine receptors. Virology, Vol.222, No.2, (August 1996), pp. 332-338, ISSN 0042-6822.

Staeheli, P., Sauder, C., Hausmann, J., Ehrensperger, F., \& Schwemmle, M. (2000). Epidemiology of Borna disease virus. J. Gen. Virol, Vol.81, No.9, (September 2000), pp.2123-2135, ISSN 1465-2099.

Staeheli, P., Sentandreu, M., Pagenstecher, A., \& Hausmann, J. (2001). Alpha/beta interferon promotes transcription and inhibits replication of Borna disease virus in persistently infected cells. J Virol, Vol.75, No.17, (September 2001), pp. 8216-8223, ISSN 1098-5514.

Stitz, L., Soeder, D., Deschl, U., Frese, K., \& Rott, R. (1989). Inhibition of immune-mediated meningoencephalitis in persistently Borna disease virus-infected rats by cyclosporine A. J Immunol, Vol.143, No.12, (December 1989), pp. 4250-4256, ISSN 1550-6606.

Sprankel, H., Richarz, K., Ludwig, H., \& Rott, R. (1978). Behavior alterations in tree shrews induced by Borna disease virus. Med Microbiol Immunol,Vol.165, No.1, (May 1978), pp. 1-18, ISSN: 1432-1831.

Stitz, L., Krey, H., \& Ludwig, H. (1980). Borna disease in rhesus monkeys as a model for uveocerebral symptoms. J Med Virol, Vol.6, pp. 333-40, ISSN 1096-9071.

Takahashi, H., Nakaya, T., Nakamura, Y., Asahi, S., Onishi, Y., Ikebuchi, K., Takahashi, T.A., Katoh, T., Sekiguchi, S., Takazawa, M., Tanaka, H., \& Ikuta, K. (1997). Higher prevalence of Borna disease virus infection in blood donors living near thoroughbred horse farms. J Med Virol, Vol.52, No.3, (July 1997), pp. 330-335, ISSN 1096- 9071.

Teplitsky, V., Pitlik, S., Richt, J.A., Herzog, S., Meir, R., Marcus, S., Sulkes, J., \& Weisman, Y. (2003). Increased prevalence of Borna disease virus ELISA and 
immunofluorescence in horses from farms situated along the paths of migratory birds. Israel Journal of Medicine, Vol.56, pp. 2-3, ISSN 1565-9052.

Terayama, H., Nishimo, Y., Kishi, M., Ikuta, K., Itoh, M., \& Iwahashi, K. (2003). Detection of anti-Borna Disease Virus (BDV) antibodies from patients with schizophrenia and mood disorders in Japan. Psychiatry Res, Vol.120, No.2, (September 2003), pp. 201206, ISSN 0165-1781.

Thakur, R., Sarma, S., \& Sarma, B. (2009). Role of Borna disease virus in neuropsychiatric illnesses: are we inching closer? Indian J Med Microbiol, Vol.27,No.3, (JulySeptember 2009), pp. 191-201, ISSN 0255-0857.

Thomas, D.R., Chalmers, R.M., Crook, B., Stagg, S., Thomas, H.V., Lewis, G., Salmon, R.L., Caul, E.O., Morgan, K.L., Coleman, T.J., Morgan-Capner, P., Sillist, M., Kench, S.M., Meadows, D., \& Softley, P. (2005). Borna disease virus and mental health: a cross-sectional study. Q J Med, Vol.98, No.4, (April 2005), pp. 247-254, ISSN 14602393.

de la Torre, J.C. (1994). Molecular biology of Borna disease virus: prototype of a new group of animal viruses. J Virol,Vol.68, No.12, (December 1994), pp.7669-7675, ISSN 1098-5514.

de la Torre, J.C. (2002). Bornavirus and the Brain. J Infect Dis, Vol.186(Suppl 2), (December 2002), pp. 241-247, ISSN 0022- 1899.

de la Torre, J.C., Gonzalez-Dunia, D., Cubitt, B., Mallory, M., Mueller-Lantzsch, N., \& Grasser, F. (1996). Detection of Borna disease virus antigen and RNA in human autopsy brain samples from neuropsychiatric patients. Virology, Vol.223, No.2, (September 1996), pp. 272-82, ISSN 0042-6822.

Torrey, E.F., \& Yolken, R.H. (2003). Toxoplasma Gondii and Schizophrenia. Emerg Infect Dis, Vol.9, No.11, (November 2003), pp. 1375-1380, ISSN 1080-6059.

Tsuji, K., Toyomasu, K., Imamura, Y., Maeda, H., \& Toyoda, T. (2000). No association of Borna disease virus with psychiatric disorders among patients in nothern Kyushu, Japan. J Med Virol, Vol.61, No.3, (July 2000), pp. 336-340, ISSN 1096-9071.

Vahlenkamp, T.W., Enbergs, H.K., \& Muller, H. (2000). Experimental and natural borna disease virus infections: presence of viral RNA in cells of the peripheral blood. Vet Microbiol, Vol.76, No.3, (October 2000), pp. 229- 244, ISSN 0378-1135.

Vahlenkamp, T.W., Konrath, A., Weber, M., \& Müller, H. (2002). Persistence of Borna Disease Virus in Naturally Infected Sheep. J Virol 2002, Vol.76, No.19, (October 2002), pp. 9735-9743, ISSN 1098-5514.

Vale, S., Espejel, M.A., \& Dominguez, J.C. (1971). Amantadine in depression. Lancet, Vol.2, No.7721, (August 1971), pp. 437, ISSN 1474-547X.

Volmer, R., Prat, Ch.M.A., Masson, G., Garenne, A., \& Gonzales-Dunia, D. (2007). Borna Disease Virus Infection Impairs Synaptic Plasticity. J Virol, Vol.81, No.16, (August 2007), pp. 8833-8837, ISSN 1098-5514.

Waltrip, R.W. 2nd, Buchanan, R.W., Carpenter, W.T. Jr, Kirkpatrick, B., Summerfelt, A., Breier, A., Rubin, S.A., \& Carbone, K.M. (1997). Borna disease virus and the deficit syndrome of schizophrenia. Schizophr Res, Vol.23, No.3, (February 1997), pp. 253257, ISSN 0920-9964.

Waltrip, R.W. 2nd, Buchanan, R.W., Summerfelt, A., Breier, A., Carpenter, W.T. Jr, Bryant, N.L., Rubin, S.A., \& Carbone, K.M. (1995). Borna disease virus and schizophrenia. Psychiatry Res, Vol.56, No.1, (January 1995), pp. 33-44, ISSN 0165-1781. 
Watanabe, Y., Yanai, H., Ohtaki, N., Ikuta, K., \& Tomonaga, K. (2006). Prevalence of Borna disease virus in healthy black cattle in Kyushu. J Vet Med Sci, Vol.68, No.2, (February 2006), pp. 171-174, ISSN 1347-7439.

Weissenbock, H., Nowotny, N., Caplazi, P., Kolodziejek, J., \& Ehrensperger, F. (1998). Borna disease in dog with lethal meningoencephalitis. J Clin Microbiol, Vol.36, No.7, (July 1998), pp. 2127-2130, ISSN 1098-660X.

Weisman, Y., Huminer, D., Malkinson, M., Meir, R., Kliche, S., Lipkin, W.I., \& Pitlik, S. (1994). Borna disease virus antibodies among workers exposed to infected ostriches. Lancet, Vol.344, No.8931, (October 1994), pp. 1232-1233, ISSN 1474-547X.

Wolff, T., Heins, G., Pauli, G., Burger, R., \& Kurth, R. (2006). Failure to detect Borna disease virus antigen and RNA in human blood. J Clin Virol, Vol.36, No.4, (August 2006), pp. 309-311, ISSN 1386-6532.

Yamaguchi, K., Sawada, T., Naraki, T., Igata-Yi, R., Shiraki, H., Horii, Y., Ishii, T., Ikeda, K., Asou, N., Okabe, H., Mochizuki, M., Takahashi, K., Yamada, S., Kubo, K., Yashiki, S., Waltrip, II R.W., \& Carbone, K.M. (1999). Detection of Borna Disease-Reactive Antibodies from Patiens with Psychiatric Disorders and from Horses by Electrochemiluminiscence Immunoassay. Clin Diagn Lab Imunol, Vol.6, No.5, (September 1999), pp. 696-700, ISSN 1556-679X.

Yang, A.Y., Zhang, F.M., Li, J.H., Li, G.M., Ma, P.L., Gu, H.X., \& Ikuta, K. (2003). Detection of Borna disease virus-p24 specific antibody in the sera of schizophrenic patients of China by means of Western-blot. Chin J Exp Clin Virol, Vol.17, No.1, (March 2003), pp. 85-87, ISSN 1003-9279. 


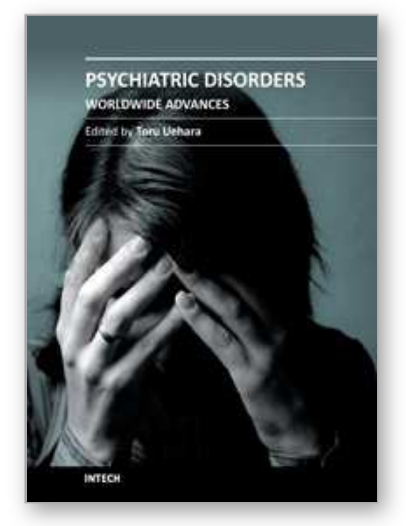

\author{
Psychiatric Disorders - Worldwide Advances \\ Edited by Dr. Toru Uehara
}

ISBN 978-953-307-833-5

Hard cover, 336 pages

Publisher InTech

Published online 03, October, 2011

Published in print edition October, 2011

A psychiatric disorder is defined as any complex condition that involves the impairment of cognitive, emotional, or behavioral functioning. Aside from knowing the physical organic factors, its causal pathology has remained a mystery. Regarding recent advances in psychiatry and neurosciences, psychiatric disorders have been closely associated with socio-cultural, psychological, biochemical, epigenetic or neural-networking factors. A need for diverse approaches or support strategies is present, which should serve as common knowledge, empathetic views or useful skills for specialists in the filed. This book contains multifarious and powerful papers from all over the world, addressing themes such as the neurosciences, psychosocial interventions, medical factors, possible vulnerability and traumatic events. Doubtlessly, this book will be fruitful for future development and collaboration in â€œworld psychiatryâ€.

\title{
How to reference
}

In order to correctly reference this scholarly work, feel free to copy and paste the following:

Sylva Rackova and Lubos Janu (2011). Borna Disease Virus and Psychiatric Disorders: Can Viruses Influence Psychiatric Disorders?, Psychiatric Disorders - Worldwide Advances, Dr. Toru Uehara (Ed.), ISBN: 978-953307-833-5, InTech, Available from: http://www.intechopen.com/books/psychiatric-disorders-worldwideadvances/borna-disease-virus-and-psychiatric-disorders-can-viruses-influence-psychiatric-disorders-

\section{INTECH}

open science | open minds

\author{
InTech Europe \\ University Campus STeP Ri \\ Slavka Krautzeka 83/A \\ 51000 Rijeka, Croatia \\ Phone: +385 (51) 770447 \\ Fax: +385 (51) 686166 \\ www.intechopen.com
}

\author{
InTech China \\ Unit 405, Office Block, Hotel Equatorial Shanghai \\ No.65, Yan An Road (West), Shanghai, 200040, China \\ 中国上海市延安西路65号上海国际贵都大饭店办公楼 405 单元 \\ Phone: +86-21-62489820 \\ Fax: +86-21-62489821
}


(C) 2011 The Author(s). Licensee IntechOpen. This is an open access article distributed under the terms of the Creative Commons Attribution 3.0 License, which permits unrestricted use, distribution, and reproduction in any medium, provided the original work is properly cited. 